\title{
Diversity and Habitat Use of Neotropical Harvestmen (Arachnida: Opiliones) in a Costa Rican Rainforest
}

\author{
Daniel N. Proud, ${ }^{1}$ Bruce E. Felgenhauer, ${ }^{1}$ Victor R. Townsend Jr., ${ }^{2}$ Daniel O. Osula, ${ }^{3}$ \\ Wyman O. Gilmore III, ${ }^{3}$ Zachery L. Napier, ${ }^{3}$ and Peter A. Van Zandt ${ }^{3}$ \\ ${ }^{1}$ Department of Biology, University of Louisiana at Lafayette, P.O. Box 42451, Lafayette, LA 70504-2451, USA \\ ${ }^{2}$ Department of Biology, Virginia Wesleyan College, 1584 Wesleyan Drive, Norfolk, VA 23502, USA \\ ${ }^{3}$ Department of Biology, Birmingham-Southern College, 900 Arkadelphia Road, Birmingham, AL 35254, USA
}

Correspondence should be addressed to Daniel N. Proud, dan.proud@louisiana.edu

Received 7 November 2011; Accepted 7 December 2011

Academic Editors: M. Kuntner and S. E. Walker

Copyright ( 92012 Daniel N. Proud et al. This is an open access article distributed under the Creative Commons Attribution License, which permits unrestricted use, distribution, and reproduction in any medium, provided the original work is properly cited.

In tropical rain forests, harvestmen assemblages are extremely diverse, with richness often exceeding 25 species. In the neotropics, there are published accounts of harvestmen faunas in South America rainforests (especially Amazonia), but relatively little is known about the community ecology of harvestmen in tropical forests of Central America. In this paper, we provide the first insights into the diverse assemblage of harvestmen inhabiting a wet forest at La Selva Biological Station, Costa Rica. Over five field seasons, we recorded 38 species. During our 2009 field season, we examined variation in species abundance, richness, and composition between adjacent successional forests (young secondary, mature secondary, and primary forests) as well as between distinct habitats (ground/litter layer and shrub/tree layer). Based on night samples (but not day), our results indicate that there are only minor differences in species composition and relative abundance between the forest ages, but no differences in richness. The ground/litter layer and shrub/tree layer habitats differed markedly in species composition, species richness, and relative abundance of several species. Our analysis of covariance supports the hypothesis that leg length is related to climbing behavior for several species belonging to Eupnoi and Laniatores.

\section{Introduction}

The order Opiliones (harvestmen) represents the third most diverse group of arachnids after mites and ticks (Acari) and spiders (Araneae). With more than 6500 described species distributed across all major continents (except Antarctica), harvestmen have become a useful group for biologists interested in investigating biogeography $[1,2]$ and monitoring the impacts of habitat disturbance and forest fragmentation [3]. Due to their relatively high abundance and rich diversity in neotropical forests, harvestmen have been characterized as potentially useful candidates for a variety of ecological studies [4]. However, the majority of field studies of harvestmen have focused on single species or a small subset of an assemblage, providing little information of interactions at the community level (see review by Curtis and Machado [4]). The few studies that have examined the community ecology of harvestmen were primarily conducted in temperate forests [5-8]. Recently, diversity and habitat use of species within neotropical communities have been investigated in Brazil $[3,9,10]$.

The most diverse harvestmen communities occur in neotropical rainforests, where richness may exceed 25 species $[1,9,11]$. The highest diversity at a single site was recorded in the Brazilian Atlantic forest with a richness of 64 species [12]. In contrast, the biodiversity of temperate communities rarely exceeds 12 species $[4,8]$. The most diverse families of the suborder Laniatores include Gonyleptidae with more than 800 species and Cosmetidae with more than 700 species [13]. Gonyleptidae is distributed from Guatemala to the southern states of Brazil, with its peak diversity in Chile, Brazil, and Peru [14]. In the Brazilian state of São Paulo, gonyleptid harvestmen represent more than 85 percent of species within a given community $[12]$ and within the entire state $[9,13]$. 
In contrast, Cosmetidae is distributed from southern parts of the United States to southern Brazil with its peak diversity occurring in Mexico, Central America, and the northern regions of South America where members of this family represent one-third to one-half of all described species in a given region [15]. In Costa Rica, Cosmetidae represents approximately half of all species, although there are many cosmetid species that remain to be described [16].

Most harvestmen are nocturnal foragers and hide in moist places during the day [4]. Individuals may undertake daily vertical migrations, descending to the leaf litter at dusk to forage $[8,17,18]$. Abiotic factors, especially temperature and humidity, significantly influence the distribution, habitat selection, and activity patterns of harvestmen $[4,6,8,19]$ as well as community structure along elevational gradients $[11,20-22]$. Other studies have examined variation in smallscale spatial distributions of harvestmen in response to biotic factors, such as vegetation and habitat structure [10, 23-26]. For example, Adams [23] found that species composition was related to leaf litter density and compressibility, but Jennings et al. [24] report very little influence of litter depth on harvestmen distributions. Corey and Stout [25] reported that harvestmen abundance was not correlated with shrub density, ground cover, or mass of plant litter. The influence of other factors on the structure of harvestmen communities, such as predation, parasitism or the availability of prey, or oviposition sites remains to be investigated [4]. However, in the case of trogulid harvestmen, which feed exclusively on snails, species distributions may reflect the distribution of their prey [27].

Phenological and ecomorphological mechanisms also influence habitat preference (reviewed by Curtis and Machado [4]). In the suborder Eupnoi, nymphs of several species commonly inhabit moist microhabitats, such as leaf litter and under logs, but migrate to higher habitat layers (e.g., vegetation and surfaces of trees) as they reach late nymph or subadult stages $[6,8,23]$. With regards to ecomorphology, leg length and number of tarsal segments have both been suggested to influence climbing behavior [4]. Identifying relationships between morphological space and ecological space (e.g., distribution, habitat use) provides a basis for testing factors that link morphology to ecology including behavior and performance (i.e., the outcome of a behavior) of an organism at an ecologically relevant task [28].

In this paper, we examine a harvestmen assemblage in a wet forest in Costa Rica and compare community composition between microhabitats within successional forest plots. We assess interspecific variation in habitat use by comparing compositional similarity, species richness, and relative abundance across the ground/litter layer and the shrub/tree layer habitats $[23,27,29]$. We also examine microhabitat selection during the day and at night. Assemblages within adjacent forest stands of different ages are compared using compositional similarity, species richness, and relative abundance. This work provides the first thorough inventory of a harvestmen community in Central America, investigates differences in habitat use by several species, and characterizes the species assemblage response to local, small-scale differences in habitat structure. Additionally, using data for habitat use and mean leg length for the most abundant species in this community, we tested the hypothesis that longer leg lengths are associated with shrub/tree layer microhabitats that involve climbing behavior.

\section{Methods}

2.1. Study Site. La Selva Biological Station, managed by Organization for Tropical Studies, is located in the province of Heredia, Costa Rica ( $10^{\circ} 25^{\prime} 50.27^{\prime \prime} \mathrm{N},-84^{\circ} 0^{\prime} 29.38^{\prime}$ W, datum: WGS84). Mainly consisting of Caribbean lowland wet forest ranging from about 35 to $150 \mathrm{~m}$ asl, La Selva encompasses approximately 1600 ha of protected land that lies adjacent to Braulio Carrillo National Park [30]. La Selva receives an average of approximately $4000 \mathrm{~mm}$ of rainfall annually with the wettest months occurring between June and December [31]. Mean monthly air temperature at the station is $25.8^{\circ} \mathrm{C}$ with little variation $\left(<3^{\circ} \mathrm{C}\right)$ between months; however, daily air temperatures may differ by $6^{\circ}-$ $12^{\circ} \mathrm{C}$ between day and night [31].

All sampling sites were selected using the land use map of La Selva from 2000 available from a geographic information systems database provided by the Organization for Tropical Studies [32]. We simplified our analysis by dividing our sites into three adjacent forests that were known to differ in time since the last major disturbance including primary forest $(>42 \mathrm{yr})$, mature secondary forest (26-42 yr), and young secondary forest (16-25yr). The elevation across the sites that we sampled was relatively constant $(35-75 \mathrm{~m}$ asl). Although categorized by age in our study, these forest stands differed in many respects including previous land use, soil types, vegetation, understory growth, and other biotic and abiotic factors. Within each forest type, we sampled ground/litter layer and shrub/tree layer habitats, a division of the vertical habitat layers in a forest, adapted from Hillyard and Sankey [27].

2.2. Collection. All specimens were captured by hand. Specimens were collected over five field seasons from 16 June to 18 August 2007, 17 June-14 August 2008, 2 June-13 July 2009, 5-20 July 2010, and 10-30 June 2011. All abundance data for habitat use were collected during the 2009 field season (Table 1) and are the main focus of this paper. Several rare species were not observed during the study of habitat use in 2009, but were collected during other field seasons (Table 2) and are therefore included in order to generate a comprehensive list of species for the station. Voucher specimens were collected and stored in 70\% ethanol for later identification and depository material. We deposited voucher specimens of most species in the collections of the American Museum of Natural History (AMNH) and the Instituto Nacional de Bioversidad (INBio, Heredia, Costa Rica).

2.3. Nocturnal Microhabitat Use. For nocturnal sampling, we sampled rotting logs and leaf litter, two microhabitats representing the ground/litter layer, as well as foliage and trees, two microhabitats representing the shrub/tree layer habitat. The four microhabitats included in this study are 
TABLE 1: Relative abundance of all species collected from log (L), litter (R), tree (T), and foliage (F) microhabitats in three adjacent forests during diurnal and nocturnal sampling. Abundance of species for diurnal samples are combined across all forest ages and reported only by microhabitat, whereas nocturnal samples show abundance by microhabitat within each forest age.

\begin{tabular}{|c|c|c|c|c|c|c|c|c|c|c|c|c|c|c|c|}
\hline \multirow{3}{*}{ Taxa } & \multirow{2}{*}{\multicolumn{2}{|c|}{ Diurnal }} & \multirow{2}{*}{\multicolumn{4}{|c|}{$\begin{array}{c}\text { Nocturnal } \\
\text { Young secondary }\end{array}$}} & \multirow{2}{*}{\multicolumn{4}{|c|}{$\begin{array}{c}\text { Nocturnal } \\
\text { Mature secondary }\end{array}$}} & \multicolumn{4}{|c|}{ Nocturnal } & \multirow{3}{*}{ Total } \\
\hline & & & & & & & & & & & & Prima & forest & & \\
\hline & $\mathrm{L}$ & $\mathrm{T}$ & $\mathrm{L}$ & $\mathrm{R}$ & $\mathrm{T}$ & $\mathrm{F}$ & $\mathrm{L}$ & $\mathrm{R}$ & $\mathrm{T}$ & $\mathrm{F}$ & $\mathrm{L}$ & $\mathrm{R}$ & $\mathrm{T}$ & $\mathrm{F}$ & \\
\hline \multicolumn{16}{|l|}{ Eupnoi } \\
\hline \multicolumn{16}{|l|}{ Sclerosomatidae } \\
\hline Metopilio ornatipes & 9 & & 23 & 23 & 2 & & 3 & 18 & & & 5 & 14 & & & 97 \\
\hline $\begin{array}{l}\text { Prionostemma } \\
\text { fuscamaculata }\end{array}$ & & 3 & & & 1 & & & & & & & & & & 4 \\
\hline Prionostemma sp. 1 & 27 & 290 & 38 & 74 & 139 & 157 & 36 & 14 & 87 & 67 & 34 & 28 & 69 & 20 & 1080 \\
\hline Prionostemma sp. 2 & 9 & 147 & 20 & 14 & 94 & 82 & 10 & 5 & 14 & 12 & 5 & 2 & 6 & 7 & 427 \\
\hline Prionostemma sp. 3 & 55 & 4 & 11 & 13 & 12 & 6 & 8 & 6 & 9 & 3 & 18 & 8 & 20 & 2 & 175 \\
\hline Prionostemma sp. 4 & 2 & & & & & & & & & & & & & & 2 \\
\hline \multicolumn{16}{|l|}{ Laniatores } \\
\hline \multicolumn{16}{|l|}{ Family uncertain } \\
\hline Costabrimma nicoyensis & 2 & & & & & & & & & & & & & & 2 \\
\hline Costabrimma terrena & 2 & & & & & & & & & & & & & & 2 \\
\hline \multicolumn{16}{|l|}{ Cosmetidae } \\
\hline Cynorta annulata & 5 & & & & & & & & 1 & & 5 & 1 & & & 12 \\
\hline Cynorta marginalis & 21 & 92 & 13 & 6 & 35 & 32 & 7 & 3 & 28 & 13 & 30 & 9 & 58 & 70 & 417 \\
\hline Eucynorta albipustulata & 8 & & 4 & 3 & 4 & & 1 & 11 & 7 & & 10 & 4 & 6 & 1 & 59 \\
\hline Eucynorta puncticulata & 9 & 1 & 6 & & & & 11 & & & & 2 & & & & 29 \\
\hline Eucynorta tenuipes & 1 & & & & & & & & & 2 & & & & 2 & 5 \\
\hline Eucynorta transversalis & 5 & & 4 & & & & 5 & & & & 5 & & & & 19 \\
\hline Eucynorta sp. 1 & 35 & & 14 & 3 & & & 17 & 7 & 3 & & 12 & 4 & 2 & & 97 \\
\hline Eucynorta sp. 2 & 1 & & & & & & & & & & & & 1 & & 2 \\
\hline Eucynorta sp. 3 & 4 & & & & 2 & & 1 & & & & 2 & & & & 9 \\
\hline Eucynorta sp. 4 & & & & & 1 & & & & & & & & & & 1 \\
\hline Eupoecilaema magnum & 1 & 2 & 1 & & 5 & 1 & & & 2 & 1 & 4 & & 4 & 1 & 22 \\
\hline Flirtea lateralis & & & 1 & & & 2 & & & & & & & & 2 & 5 \\
\hline Meterginus inermipes & 9 & & 1 & & & & & & & & & & & & 10 \\
\hline Paecilaema sp. 1 & 40 & 3 & 13 & 4 & 2 & 3 & 13 & 5 & 8 & 2 & 32 & 10 & 15 & 7 & 157 \\
\hline Paecilaema sp. 2 & 3 & & & & & & & & & & & & & & 3 \\
\hline \multicolumn{16}{|l|}{ Gonyleptidae } \\
\hline Glysterus sp. 1 & 39 & & 36 & 34 & 1 & & 27 & 33 & 2 & & 24 & 25 & & & 221 \\
\hline Hernandriaspinosa & 7 & & 2 & 1 & 1 & & & & & & & 1 & & & 12 \\
\hline \multicolumn{16}{|l|}{ Stygnommatidae } \\
\hline Stygnomma furhmanni & 20 & & 2 & 1 & & & 4 & 2 & & & 11 & & & & 40 \\
\hline \multicolumn{16}{|l|}{ Zalmoxidae } \\
\hline Ethobunus albitrochanteris & 112 & & 62 & 36 & 3 & & 43 & 17 & 1 & 1 & 18 & 20 & 3 & & 316 \\
\hline Ethobunus sp. & 2 & & & 1 & & & 2 & 1 & & & & 4 & & & 10 \\
\hline Pachylicus rugosus & 8 & & 7 & 2 & & & 4 & 5 & & & 2 & 3 & & & 31 \\
\hline Pachylicus spinatus & 5 & & 6 & 4 & & & 2 & 3 & & & 2 & & & & 22 \\
\hline Panopiliops reimoseri & 13 & 1 & & 3 & & & 1 & 1 & & & 1 & & & & 20 \\
\hline Phalangoduna granosa & 4 & & 1 & & & & 2 & & & & & & & & 7 \\
\hline Stygnoleptes analis & & & & & & & & 1 & & & & & & & 1 \\
\hline Total abundance & 458 & 543 & 265 & 222 & 302 & 283 & 197 & 132 & 162 & 101 & 222 & 133 & 184 & 112 & 3316 \\
\hline Richness & 29 & 9 & 20 & 16 & 14 & 7 & 19 & 16 & 11 & 8 & 19 & 14 & 10 & 9 & 33 \\
\hline
\end{tabular}


TABLE 2: Locations of rare species collected from La Selva Biological Station during 2010 and 2011 field seasons that were not collected in 2009.

\begin{tabular}{lc}
\hline Taxa & Location \\
\hline Cosmetidae & \\
Cynorta sp. & Bromeliad, on a tree $30 \mathrm{~m}$ above ground \\
Cynortellana oculata & Ground-layer vegetation \\
Cynortula sp. & Ground-layer vegetation \\
Poecilaemula signata & Fern, on a tree $25 \mathrm{~m}$ above ground \\
Gonyleptidae & \\
Glysterus sp. 2 & Beneath a rotting log \\
\hline
\end{tabular}

referred to as logs, litter, foliage, and trees throughout the paper. We sampled microhabitats along $50 \mathrm{~m}$ transects in each of the three forest types including primary $(n=11$ transects), mature secondary $(n=9)$, and young secondary $(n=9)$ forests. Sampling was completed between 2000 and $0100 \mathrm{~h}$. We standardized sampling effort by controlling the time (30 min) allowed to walk the entire transect. All samples were collected within $5 \mathrm{~m}$ on either side of the transect line.

For logs, we scanned the surface of any woody cover object, rolled the object to search underneath it, and if possible we broke it apart to search in small cavities. For leaf litter, leaves were raked into a small pile, carefully sifted by hand, and the soil under the leaf litter was inspected for movement of small species that often use thanatosis as a defense mechanism. For foliage, we inspected all shrubs, ferns, and saplings that were less than $2.5 \mathrm{~m}$ and searched on leaves, branches, and stems. Finally, we searched the surfaces of large trees as well as tree buttresses from the ground level up to $2.5 \mathrm{~m}$.

2.4. Diurnal Microhabitat Use. During the day (0900$1600 \mathrm{~h}$ ), we only sampled logs and surfaces of tree trunks below $2.5 \mathrm{~m}$, since harvestmen rarely occurred in the other microhabitats. Assessing microhabitat use and species distributions for these microhabitats is difficult because data often contain many samples with zero observations due to the patchiness of spatial distributions [22]. Therefore, sampling sites were randomly selected from the La Selva land use map. At each site, we haphazardly sampled five logs and five trees. The maximum distance between the five logs or trees within a site was $100 \mathrm{~m}$. We sampled 11 sites for logs and 11 sites for trees in young secondary, mature secondary, and primary forests ( $n=66$ sites). The relative abundance for each site was calculated as the sum of all individuals collected from the five logs or trees at that site. Methods for searching logs and trees and collecting individuals were similar to those described for nocturnal sampling.

2.5. Composition, Richness, and Abundance. To examine the compositional similarity among microhabitats within the three forest ages, we transformed data using $\log (x+1)$, computed pairwise abundance-based Bray-Curtis dissimilarities, analyzed the dissimilarity matrix using nonmetric multidimensional scaling (NMDS), and plotted the first two axes using the ecodist package [33] in R [34]. Ellipses representing the standard deviation were plotted. Vector fitting was used to fit individual variables (species) to the ordination to illustrate indicator species associated with a particular forest age or microhabitat. To test the statistical significance of the NMDS analysis, a permutational analysis of variance (ANOVA) was employed using the function adonis of the vegan package [35] available in $\mathrm{R}$.

To compare species richness among forest ages and microhabitats, we constructed expected species accumulation curves based on the observed species richness (Mao Tau) with 95\% CI generated by analytical computations performed in EstimateS 8.0 [36]. Species accumulation curves were scaled by the number of individuals observed rather than the number of samples, as recommended by Gotelli and Colwell [37].

Based on results from the NMDS, we combined samples for similar microhabitats in order to facilitate comparisons of abundance for different vertical habitat layers. We compared the relative abundance for the ground/litter layer (i.e., the sum of litter and logs) and shrub/tree layer (i.e., the sum of foliage and trees) within each of the three forest ages for day and night. For diurnal sampling, only the relative abundance for the entire harvestmen assemblage was compared among groups. For nocturnal sampling, we followed methods of Bragagnolo et al. [3] and calculated relative abundance for the entire harvestmen assemblage, individually for the most common species (for which we collected at least 100 individuals) and for the combined abundance of all uncommon and rare species ( $<100$ individuals collected). Data were not normal and variances were heterogeneous; therefore, we used nonparametric Kruskal-Wallis (KW) tests. In order to simplify the KW test, we crossed the levels of our two factors (habitat and forest age) to generate a single factor with six levels. We tested for differences among groups $(\mathrm{df}=5)$ using the KW test $(\alpha=0.01)$. For multiple comparisons following the KW test, we adjusted the level of significance by dividing the original alpha level ( $\alpha=0.05)$ by the number of comparisons $(n=15)$ and followed the methods outlined by Daniel [38] for Dunn's test for multiple comparisons. Abundances are shown as box plots which indicate the median, lower and upper quartiles, minimum and maximum, and outliers. Analyses were performed in R [34].

Nymphs were excluded from the species abundance data because identifying nymphs to the species level proved difficult for early instars of cosmetid and sclerosomatid harvestmen due to the lack of defining morphological characters (e.g., sexually dimorphic characters, dorsal armature, coloration of dorsal scute). Therefore, we calculated the relative abundance of nymphs for Cosmetidae spp., Prionostemma spp., Glysterus sp. 1, Ethobunus albitrochanteris [39], and Stygnomma fuhrmanni [40] (Table 3). Although we did not perform statistical tests for these data, we report the relative abundances to illustrate the habitat preference of nymphs.

Collection methods differed slightly for diurnal and nocturnal sampling (as described above). Therefore, we conducted all analyses separately for diurnal and nocturnal 
TABle 3: Abundance of nymphs collected from ground/litter layer (GL) and shrub/tree layer (FT) habitats during diurnal and nocturnal sampling.

\begin{tabular}{lcccc}
\hline \multirow{2}{*}{ Taxa } & \multicolumn{2}{c}{ Diurnal } & \multicolumn{2}{c}{ Nocturnal } \\
& GL & ST & GL & ST \\
\hline Prionostemma spp. & 76 & 6 & 35 & 4 \\
Cosmetidae spp. & 71 & 4 & 122 & 23 \\
Glysterus sp. 1 & 28 & 0 & 32 & 0 \\
Ethobunus albitrochanteris & 5 & 0 & 7 & 0 \\
Stygnomma fuhrmanni & 13 & 0 & 8 & 0 \\
\hline
\end{tabular}

samples in order to examine differences among forest ages and habitat use.

2.6. Leg Length and Climbing Behavior. We decided to explore our data for patterns that might relate leg length to climbing behavior. In order to investigate this possible relationship, we calculated the mean body length, mean leg length for leg II and leg IV, and number of tarsal segments for legs I, II, III, and IV of adult male harvestmen ( $n=6$ for each species) for the ten most common species observed during nocturnal sampling (Table 4). We applied a principle components analysis (PCA) to examine variables for collinearity and found that all leg lengths and numbers of tarsal segments were strongly correlated. Therefore, we chose to use length of leg IV as the predictor variable and omit other strongly correlated predictor variables as suggested by Quinn and Keough [41]. For each of the ten species, we computed the proportion of individuals that were collected from the shrub/tree layer (i.e., proportion of climbing individuals). We applied an analysis of covariance (ANCOVA) to examine the effect of mean length of leg IV on climbing behavior (measured by the proportion of individuals collected from the shrub/tree layer). Due to morphological differences between species belonging to Eupnoi and Laniatores, we included suborder as a factor (levels $=2$ ) in the analysis. This analysis was performed using $\mathrm{R}$ [34].

\section{Results}

3.1. Harvestmen Abundance. On the basis of our collections from 2007-2011, we identified 38 species at La Selva representing six families (Tables 1 and 2), including the Cosmetidae (19 species), Gonyleptidae ( 3 species), Stygnommatidae (1 species), Zalmoxidae (7 species), and two species of the genus Costabrimma (familial assignment uncertain). These families belong to the suborder Laniatores [13]. We also collected six species for the Sclerosomatidae, a taxon from the suborder Eupnoi. Of the 38 species at La Selva, we were unable to confirm the identities of 16 species (Figures 1, $2,3)$.

During 2009, our diurnal sampling resulted in the collection of 1001 adult harvestmen representing 30 species. We collected 458 adults from logs and 543 individuals from the surfaces of trees during the day (Table 1). There was no significant difference in relative abundance among groups (KW $\left.\chi^{2}=4.189, \mathrm{df}=5, P=0.5225\right)$. The most abundant species on the trees were Prionostemma sp. $1(n=290)$, Prionostemma sp. $2(n=147)$, and Cynorta marginalis [42] $(n=92)$, together comprising 97.4 percent of the total harvestmen. In comparison, the most abundant harvestmen found in logs were Ethobunus albitrochanteris $(n=112)$, Prionostemma sp. $3(n=55)$, Paecilaema sp. $1(n=40)$, Glysterus sp. $1(n=39)$, and Eucynorta sp. $1(n=35)$, which made up 61.3 percent of the individuals.

Nocturnal sampling (i.e., leaf litter, logs, foliage, and trees) resulted in the collection of 2315 adult harvestmen representing 30 species (Table 1). Abundance of harvestmen for both the shrub/tree layer and ground/litter layer in young secondary forest was significantly higher compared to other forest ages (Figure 4). Results of all KW tests and pairwise comparisons are shown in Figure 4.

3.2. Species Richness and Evenness. For diurnal sampling, species richness was significantly higher for logs in young secondary (26 species; 95\% CI: 19.31-32.69), mature secondary ( 23 species; 95\% CI: 16.41-29.59), and primary (18 species; 95\% CI: 11.54-24.46) forests compared to trees in young secondary (5 species; 95\% CI: 0.91-9.09), mature secondary ( 8 species; 95\% CI: 2.97-13.03), and primary (5 species; 95\% CI: 0.91-9.09) forests (Figure 5(a)). We collected a total of 29 species from logs while only 9 species were collected from trees (Table 1). The difference in evenness between logs and trees during the day is also illustrated by the much greater slope for logs on the species accumulation curve compared to the relatively small slope for trees (Figure 5(a)). The observed species richness did not differ significantly between forest ages.

The species accumulation curves for night transects illustrate the differences in richness and evenness among the four microhabitats (Figures $5(\mathrm{~b})-5(\mathrm{~d})$ ). The only significant difference was between logs and foliage. Logs exhibited the greatest species richness for all three forest ages, while foliage exhibited the lowest richness (Figures $5(\mathrm{~b})-5(\mathrm{~d})$ ). The steeper slope of the species accumulation curves for logs and leaf litter indicate much higher evenness compared to trees and foliage (Figures $5(\mathrm{~b})-5(\mathrm{~d})$ ). Species evenness was especially low for tree and foliage microhabitats in young secondary forest (Figure 5(b)) which was dominated by Prionostemma spp. 1 and 2. No differences in species richness were observed between forest ages for similar microhabitats (Figures 5(b)-5(d)).

3.3. Species Associations. With regards to the daytime sampling of tree and $\log$ microhabitats in the three forest ages, the NMDS ordination plots illustrate that there was no difference in species composition between forest ages (Figure 6(a)), but there was a significant difference in species composition between microhabitats (Figure 6(b)). Results of the permutational ANOVA confirmed that species composition differed significantly among the log and tree microhabitats $\left(R^{2}=0.389 ; F_{1,60}=40.71 ; P<0.001\right)$, but no significant difference was detected among forest ages $\left(R^{2}\right.$ $\left.=0.016 ; F_{2,60}=0.829 ; P=0.570\right)$ or the interaction term 
TABle 4: Proportion of individuals climbing (PC), mean body length and leg length, and number of tarsal segments for the ten most abundant species included in an analysis of covariance to assess the relationship between proportion climbing and mean leg IV length. Mean lengths and tarsal count are based on measurements for six adult males of each species.

\begin{tabular}{|c|c|c|c|c|c|}
\hline Species & $\mathrm{PC}$ & $\begin{array}{c}\text { Body } \\
(\mathrm{mm} \pm \mathrm{SD})\end{array}$ & $\begin{array}{c}\text { Leg II } \\
(\mathrm{mm} \pm \mathrm{SD})\end{array}$ & $\begin{array}{c}\text { Leg IV } \\
(\mathrm{mm} \pm \mathrm{SD})\end{array}$ & Tarsal segments \\
\hline \multicolumn{6}{|l|}{ Laniatores } \\
\hline Cynorta marginalis & 0.7763 & $5.33 \pm 0.64$ & $43.95 \pm 4.11$ & $43.48 \pm 5.55$ & $6: 13-16: 9-11: 10-12$ \\
\hline Eucynorta albipustulata & 0.3529 & $7.08 \pm 0.27$ & $31.45 \pm 0.77$ & $29.82 \pm 0.87$ & $6: 13-16: 7: 8$ \\
\hline Paecilaema sp. 1 & 0.3246 & $5.55 \pm 0.25$ & $38.95 \pm 0.99$ & $32.58 \pm 0.55$ & $7: 14-16: 8-9: 9-10$ \\
\hline Eucynorta sp. 1 & 0.0806 & $4.30 \pm 0.16$ & $18.97 \pm 1.02$ & $18.08 \pm 0.38$ & $6: 11-12: 7: 8-9$ \\
\hline Ethobunus albitrochanteris & 0.0392 & $2.88 \pm 0.13$ & $18.30 \pm 4.11$ & $25.92 \pm 7.44$ & $3: 7: 5: 6$ \\
\hline Glysterus sp. 1 & 0.0165 & $5.83 \pm 0.18$ & $15.15 \pm 0.58$ & $16.48 \pm 0.45$ & $5: 8-9: 6: 6$ \\
\hline \multicolumn{6}{|l|}{ Eupnoi } \\
\hline Prionostemma sp. 2 & 0.7934 & $4.03 \pm 0.24$ & $114.57 \pm 5.82$ & $73.65 \pm 3.26$ & $36-38: 100-107: 32-34: 36-38$ \\
\hline Prionostemma sp. 1 & 0.7064 & $5.77 \pm 0.19$ & $105.00 \pm 3.59$ & $66.58 \pm 2.05$ & $36-37: 107-125: 32-34: 36-38$ \\
\hline Prionostemma sp. 3 & 0.4483 & $3.26 \pm 0.37$ & $58.65 \pm 2.23$ & $36.92 \pm 1.63$ & $30-31: 77-95: 26-30: 30-31$ \\
\hline Metopilio ornatipes & 0.0227 & $4.32 \pm 0.16$ & $21.05 \pm 0.57$ & $14.65 \pm 0.45$ & $21-23: 4762: 16-21: 21-24$ \\
\hline
\end{tabular}

of microhabitat $\times$ forest age $\left(R^{2}=0.023 ; F_{2,60}=1.180\right.$; $P=0.283)$. Fitting vectors to the ordination plots indicated that C. marginalis, Prionostemma sp. 1, and Prionostemma sp. 2 were strongly correlated with trees, while Cynorta annulata [43], E. albitrochanteris, Eucynorta albipustulata [40], Eucynorta transversalis [39], Eucynorta sp. 1, Glysterus sp. 1, Paecilaema sp. 1, Metopilio ornatipes [42], Pachylicus rugosus [42], Prionostemma sp. 3, and S. fuhrmanni were all correlated with logs (all $P<0.05$; vectors for some species illustrated in Figure 6(b)).

The NMDS results for night transect data demonstrated clear differences between microhabitats (Figure 6(c)), but only slight differences among forest ages mainly between young secondary and primary forests (Figure $6(\mathrm{~d})$ ). The permutational ANOVA of the Bray-Curtis dissimilarity matrix showed significant differences among microhabitats and forest ages. The analysis revealed that differences in species composition between microhabitats explained the most variation in the model $\left(R^{2}=0.348 ; F_{3,104}=23.39\right.$; $P<0.001)$, forest ages explained much less variation $\left(R^{2}\right.$ $\left.=0.080 ; F_{2,104}=8.08 ; P<0.001\right)$, and microhabitats $\times$ forest ages explained the least variation $\left(R^{2}=0.055 ; F_{6,104}\right.$ $=1.85 ; P=0.02)$. There was a high degree of similarity within $\log$ and leaf litter microhabitats and within tree and foliage microhabitats; however, species composition of logs and leaf litter was much different from that of trees and foliage (Figure 6(c)). Vector fitting revealed several indicator species that contributed significantly (all $P<0.05$ ) to the differences observed among microhabitats. Cynorta marginalis, Eupoecilaema magnum [39], Prionostemma sp. 1, and Prionostemma sp. 2 were most closely associated with the tree and foliage microhabitats. Ethobunus sp., E. albitrochanteris, Eucynorta sp. 1, E. transversalis, Glysterus sp. 1, M. ornatipes, P. rugosus, Pachylicus spinatus Goodnight and Goodnight 1983, Paecilaema sp. 1, and S. fuhrmanni were most closely associated with log and leaf litter microhabitats (vectors for some species are illustrated in Figure 6(d)).
3.4. Leg Length and Climbing Behavior. The ANCOVA was statistically significant (Adjusted $R^{2}=0.8895, F_{3,6}=25.15$, $P<0.001)$. The significant interaction between leg length and suborder on the proportion of individuals climbing indicates that the slopes of the relationships between leg length and proportion of individuals climbing differed for the two taxa (Figure $7 ; F_{1,6}=7.876, P=0.031$ ). The slope of this relationship was much greater for Laniatores (slope $=0.2708, \mathrm{SE}=0.0522)$ than for Eupnoi (slope $=$ $0.1224, \mathrm{SE}=0.0222$ ). The lack of a significant effect of suborder on proportion of individuals climbing indicates that the intercepts of the relationship between leg length and proportion climbing did not differ (Figure $7 ; F_{1,6}=0.964$, $P=0.364$ ) between Laniatores (intercept $=-0.4872, \mathrm{SE}$ $=0.1822$ ) and Eupnoi (intercept $=-0.1045, \mathrm{SE}=0.1191$ ). These results suggest that while leg lengths are similar for short-legged, ground-dwelling species for both taxa, an increase in leg length in species belonging to Laniatores results in a more rapid shift from ground level habitats to elevated habitats compared to species of Eupnoi.

\section{Discussion}

4.1. Diversity at La Selva. Over the course of five field seasons (2007-2011) at La Selva Biological Station, we have collected 38 species of harvestmen representing six families (Figures 1, 2, 3). During 2009, we sought to examine patterns of diversity and habitat use within this harvestmen community by comparing nocturnal and diurnal samples taken from four microhabitats in three adjacent, successional forests. Five species were not collected during 2009 (Table 2), but are known from collections during other field seasons. These species exhibit very low abundance at this site and may use microhabitats that were not included in our sampling methods (e.g., bromeliads and forest canopy).

The harvestmen community of La Selva exhibits many of the structural features of other harvestmen communities 


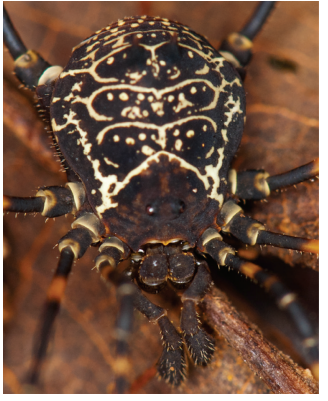

(a)

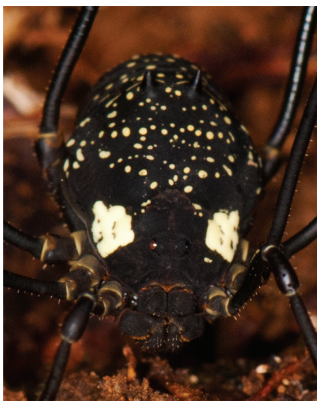

(f)

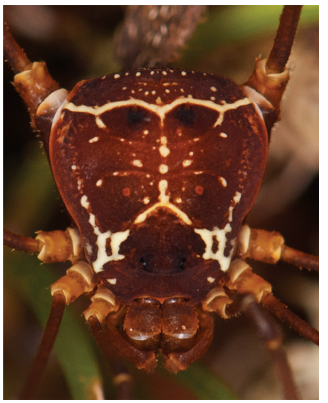

(k)

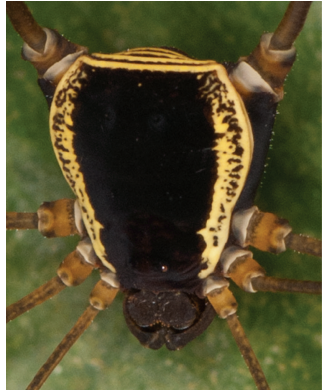

(b)

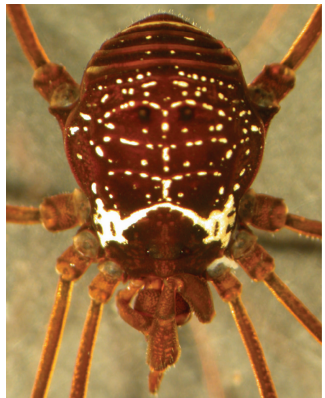

(g)

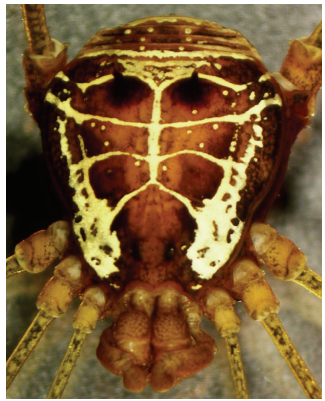

(1)

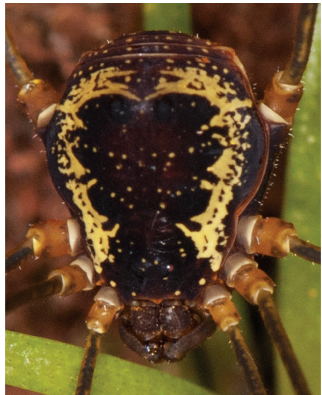

(c)

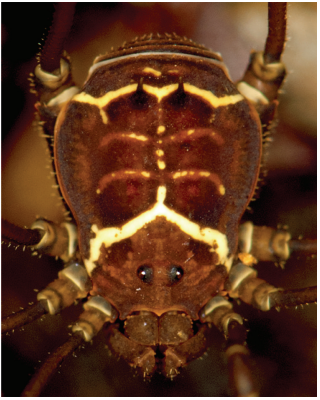

(h)

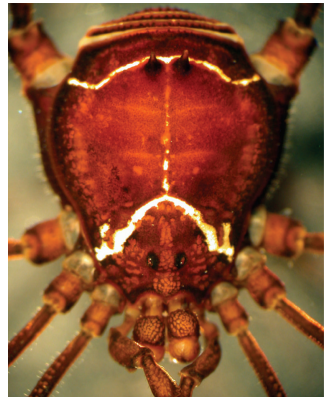

(m)

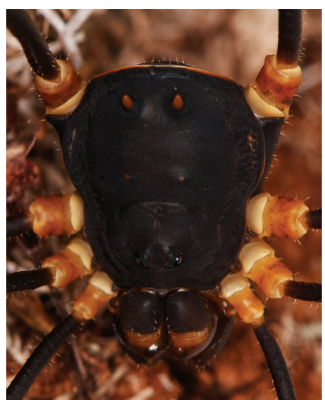

(p)

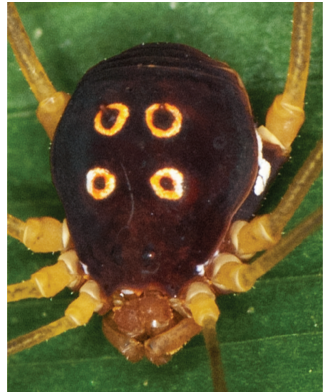

(d)

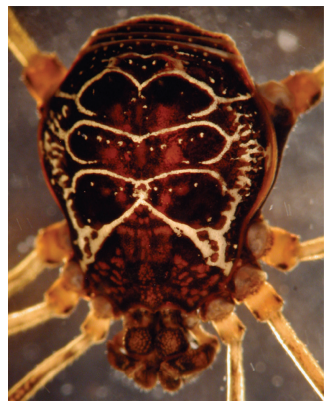

(i)

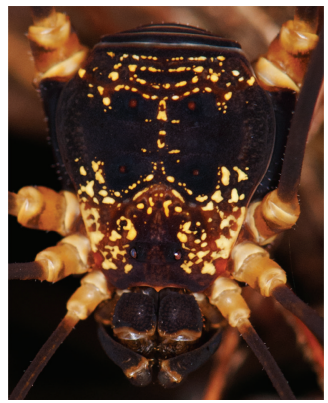

(n)

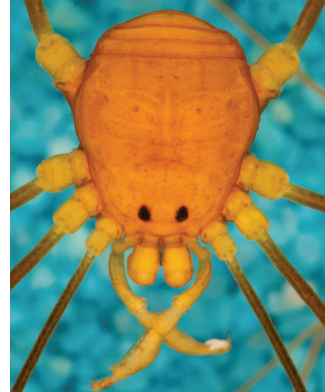

(e)

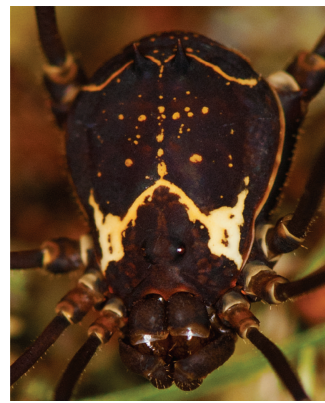

(j)

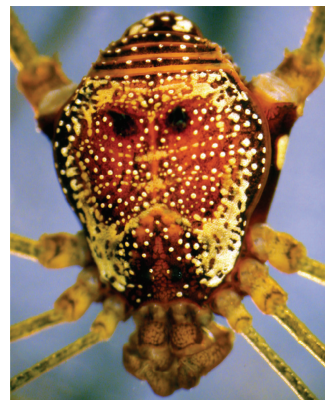

(o) Cynortellana oculata, (e) Cynortula sp., (f) Eucynorta albipustulata, (g) E. puncticulata, (h) Eucynorta sp. 1, (i) Eucynorta sp. 2, (j) Eucynorta sp. 3, (k) Eucynorta sp. 4, (1) E. tenuipes, (m) E. transversalis, (n) Eupoecilaema magnum, (o) Flirtea lateralis, and (p) Meterginus inermipes.

in tropical and subtropical forests $[1,3,12,22]$. In our paper, the suborder Eupnoi was represented by six species, but two species, Prionostemma sp. 1 and Prionostemma sp. 2, made up 45.4 percent of all the individuals collected. The Laniatores were represented by 30 species, with the most abundant taxa being C. marginalis (12.6\%), E. albitrochanteris (9.5\%), and S. fuhrmanni (6.7\%), belonging to Cosmetidae, Zalmoxidae, and Stygnommatidae, respectively. Bragagnolo et al. [3] found a very similar pattern of species composition in a Brazilian Atlantic forest in which 63 percent of individuals were represented by two species belonging to Sclerosomatidae, and 15 percent were 


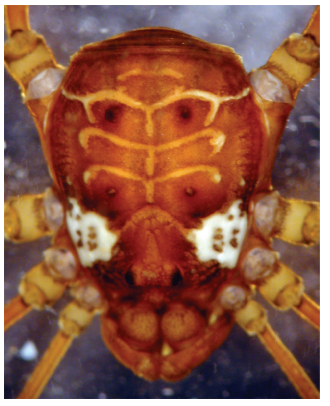

(a)

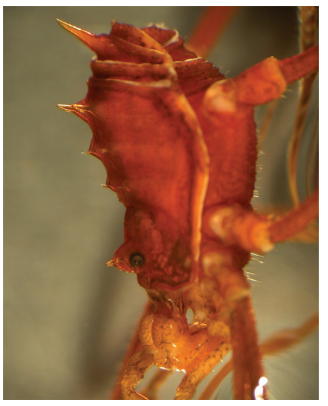

(f)

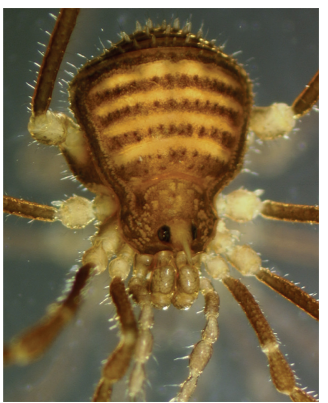

(k)

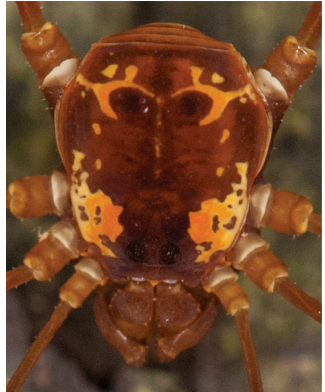

(b)

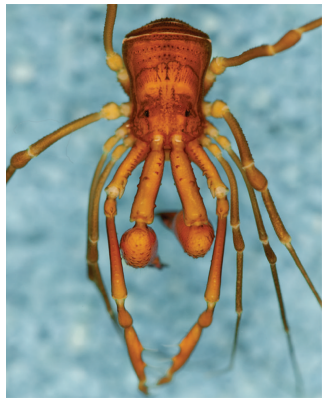

(g)

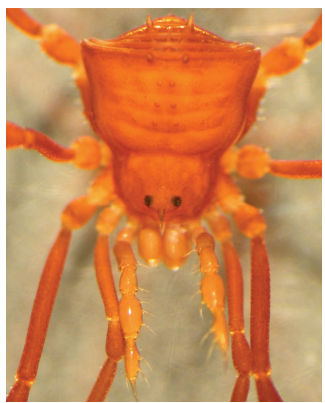

(1)

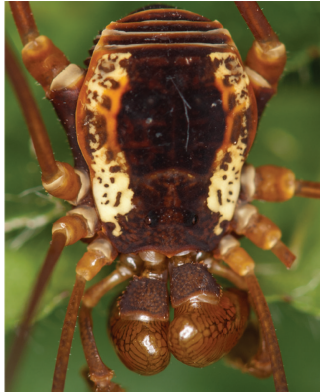

(c)

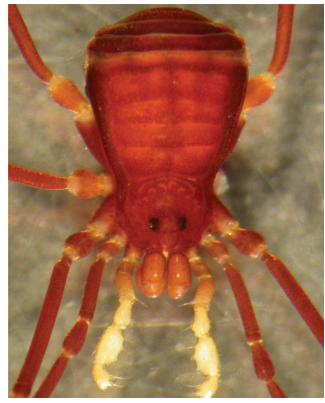

(h)

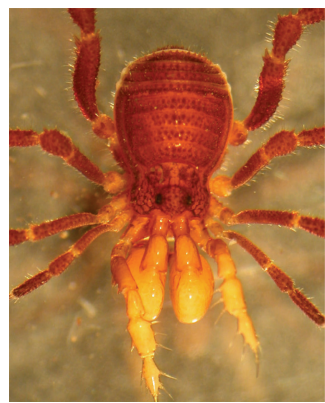

(m)

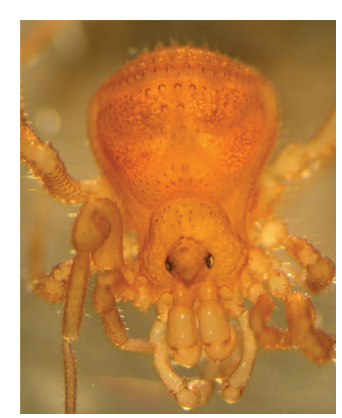

(p)

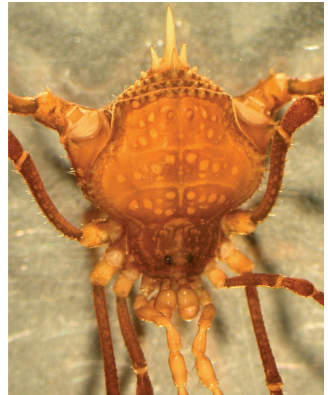

(d)

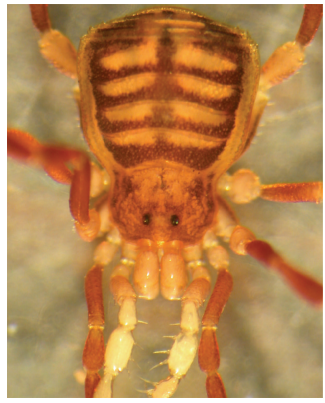

(i)

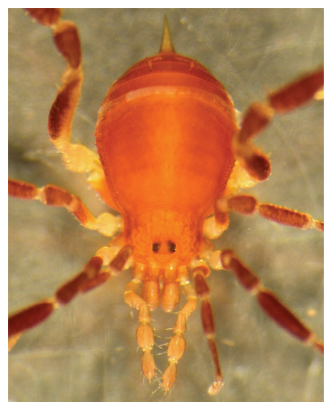

(n)

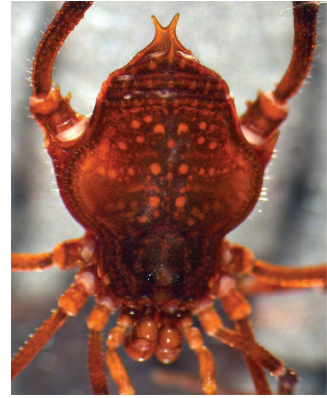

(e)

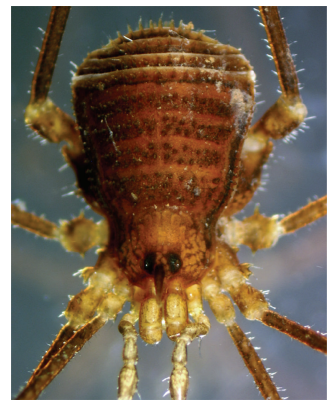

(j)

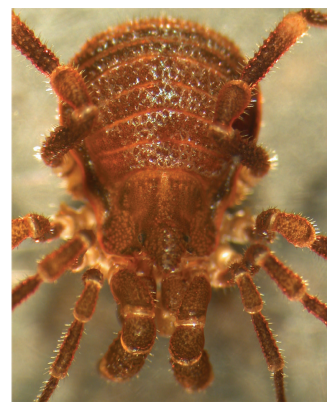

(o)

) 


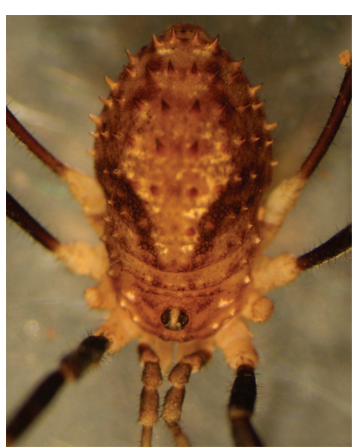

(a)

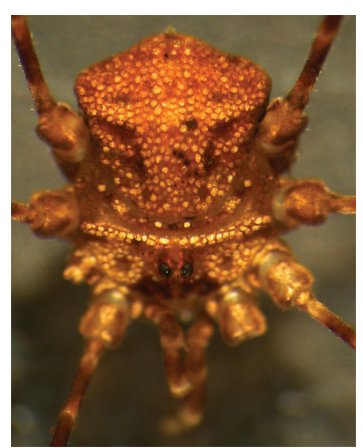

(b)

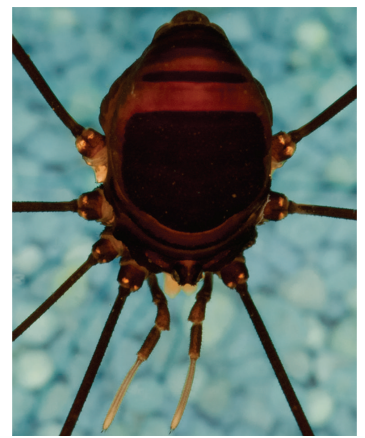

(e)

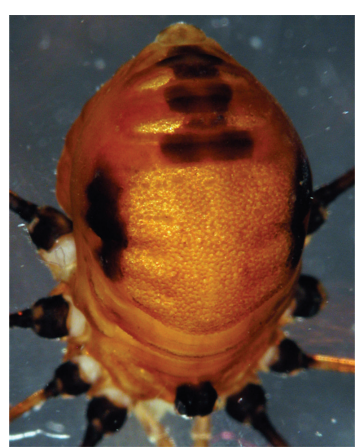

(c)

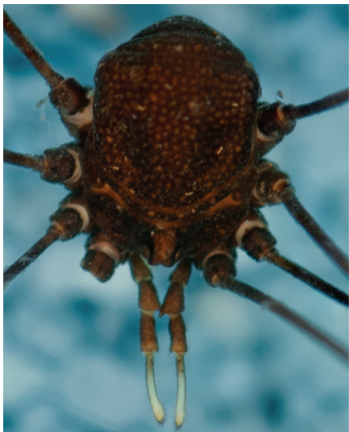

(f)

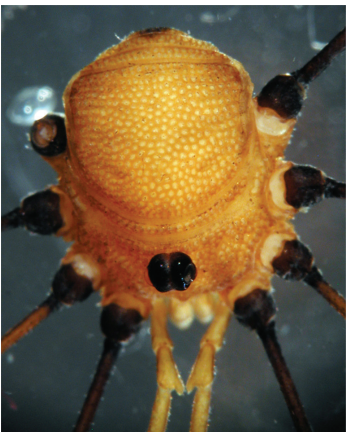

(d)

Figure 3: Photographs of harvestmen of La Selva from the family Sclerosomatidae (Eupnoi): (a) Metopilio ornatipes, (b) Prionostemma fuscamaculata, (c) Prionostemma sp. 1, (d) Prionostemma sp. 2, (e) Prionostemma sp. 3, and (f) Prionostemma sp. 4.

4.2. Habitat Use. We examined interspecific variation in species composition between ground/litter layer microhabitats (logs and leaf litter) and shrub/tree layer microhabitats (foliage and trees). While many species were most commonly associated with leaf litter and logs (ground dwelling species), others were more common on trees and foliage (climbing species). Diversity was greatest for the ground/litter layer habitat (26 species, 5 families) and included Paecilaema sp. 1 (Cosmetidae), M. ornatipes (Sclerosomatidae), E. albitrochanteris (Zalmoxidae), S. fuhrmanni (Stygnommatidae), and Glysterus sp. 1 (Gonyleptidae) among others. In contrast, the majority of climbing individuals were represented by only three species, specifically Prionostemma sp. 1, Prionostemma sp. 2 (Sclerosomatidae), and C. marginalis (Cosmetidae). We also found these species walking across leaf litter and occasionally on the surface of rotting logs. While searching tree buttresses, we observed that several individuals that we had disturbed in the leaf litter would begin climbing the trees. These individuals included adult $M$. ornatipes (Sclerosomatidae), Glysterus sp. (Gonyleptidae), and Hernandria spinosa [42] (Gonyleptidae), species that did not typically occur in this microhabitat.

The low species richness observed on trees during the day suggests that many harvestmen use other microhabitats as diurnal refuges, but climb on vegetation at night, presumably to forage or find mates. In fact, most of our observations regarding feeding were made for individuals climbing on vegetation. In several cases, we observed adult Prionostemma sp. 1 and sp. 2 feeding on oligochaetes while perched on vegetation more than one meter from the ground. Similar behaviors have been observed for temperate species that forage on the ground and move to an elevated site following prey capture $[5,6,8,44,45]$. The sclerosomatid harvestman, Leiobunum rotundum [46], waits for prey on the underside of leaves but moves to the upper side of the leaf to consume prey [6].

Individuals of Prionostemma spp. 1 and 2 make vertical migrations during the day [18], similar to behaviors described by Todd [6] for the sclerosomatid L. rotundum. Our data also support this pattern. During the day, more than $90 \%$ of individuals representing Prionostemma spp. 1 and 2 were collected from the shrub/tree layer (i.e., trees only); in contrast, during nocturnal sampling we collected approximately $70 \%$ of individuals belonging to these two species from this elevated habitat (i.e., trees and foliage). Thus, a larger proportion of individuals were found actively walking in the ground/litter layer at night.

Day time sampling probably underestimates the relative abundance of harvestmen because many individuals may occupy perches that are simply too far above the ground to be observed. Our sampling method limited data collection to individuals no higher than $2.5 \mathrm{~m}$. Individuals of several cosmetid species may make daily vertical migrations [47] or may occupy microhabitats higher in the canopy. For example, we collected individuals for two species in 2011 that were not collected in 2009 including one adult female Cynorta sp. collected from a bromeliad approximately $30 \mathrm{~m}$ above the ground and one adult male Poecilaemula signata 


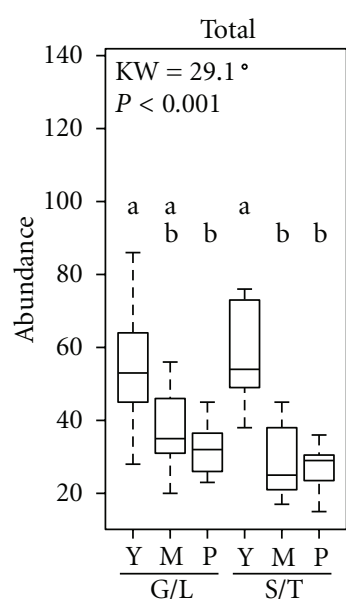

(a)

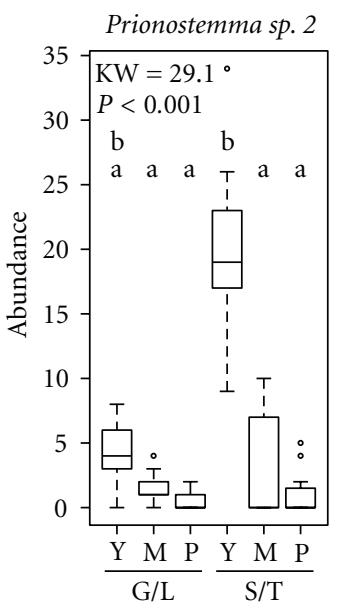

(e)

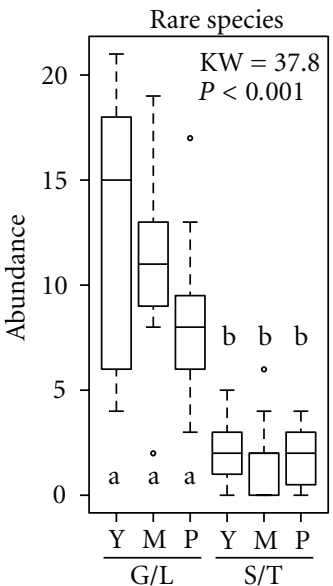

(b)

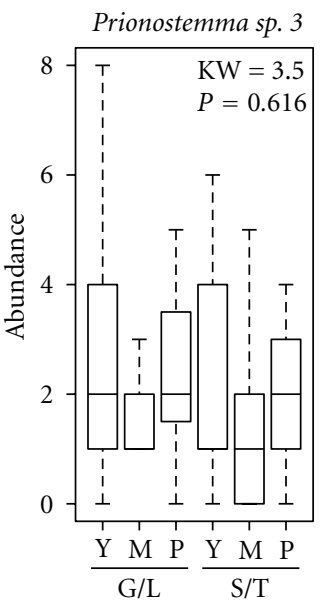

(f)

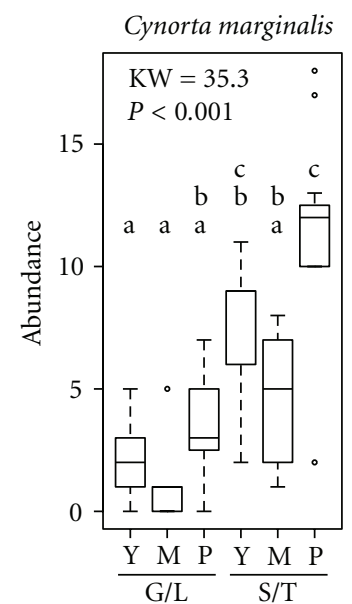

(c)

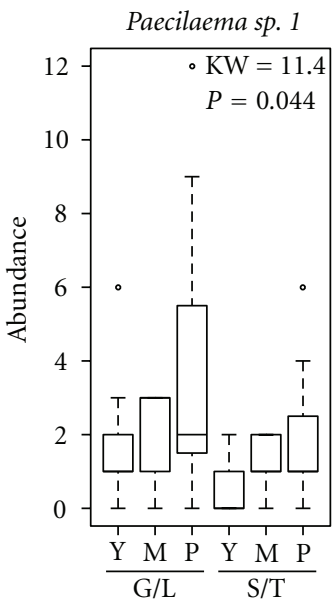

(g)

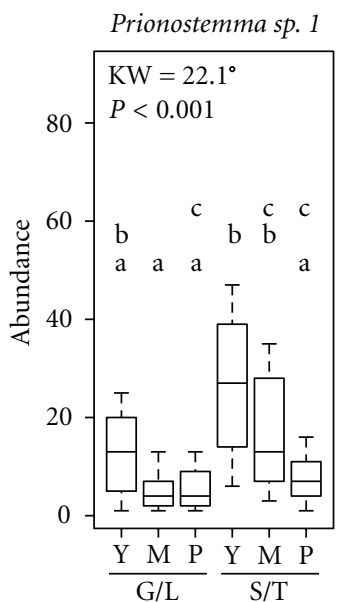

(d)

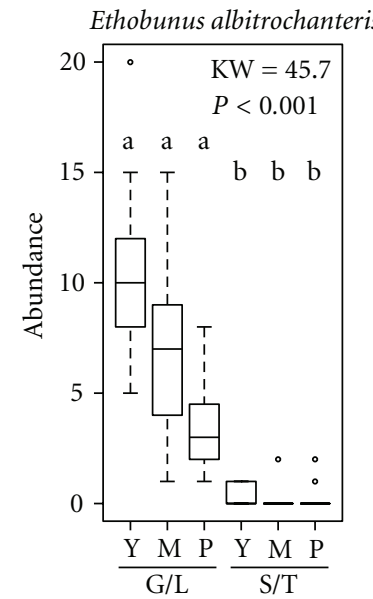

(h)

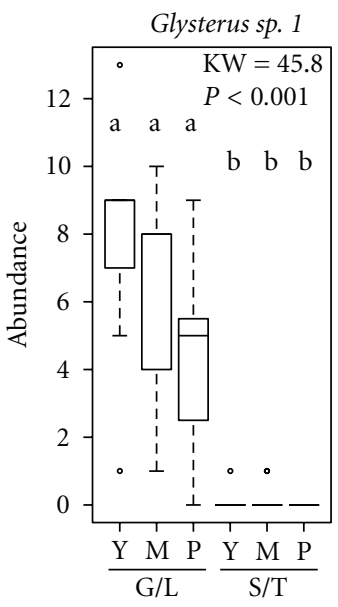

(i)

FIgURE 4: Box-and-whisker plots showing median abundance calculated for the entire assemblage, rare species (less than 100 individuals captured), and the seven most common species (more than 100 individuals captured) collected from the shrub/tree layer (S/T) and ground/litter layer $(\mathrm{G} / \mathrm{L})$ within young secondary $(Y ; n=9)$, mature secondary $(M ; n=9)$, and primary $(P ; n=11)$ forests. Thick horizontal bar represents the median, boxes indicate upper and lower quartiles, whiskers include data points within 1.5 times the interquartile range and circles represent outliers. The results of each Kruskal-Wallis test among groups $(\mathrm{df}=5)$ are shown. Statistically different pairwise comparisons based on Dunn's test for multiple comparisons are indicated by different letters. 

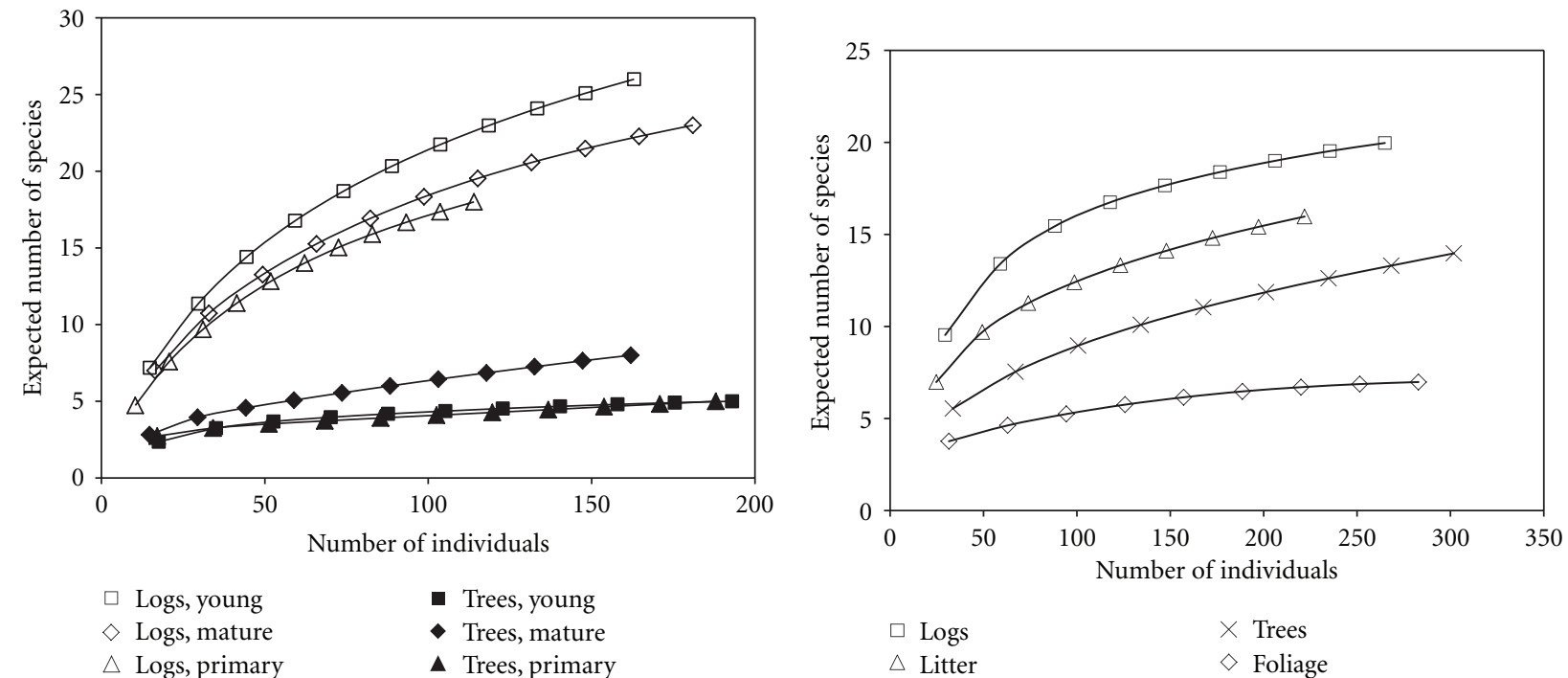

(a)

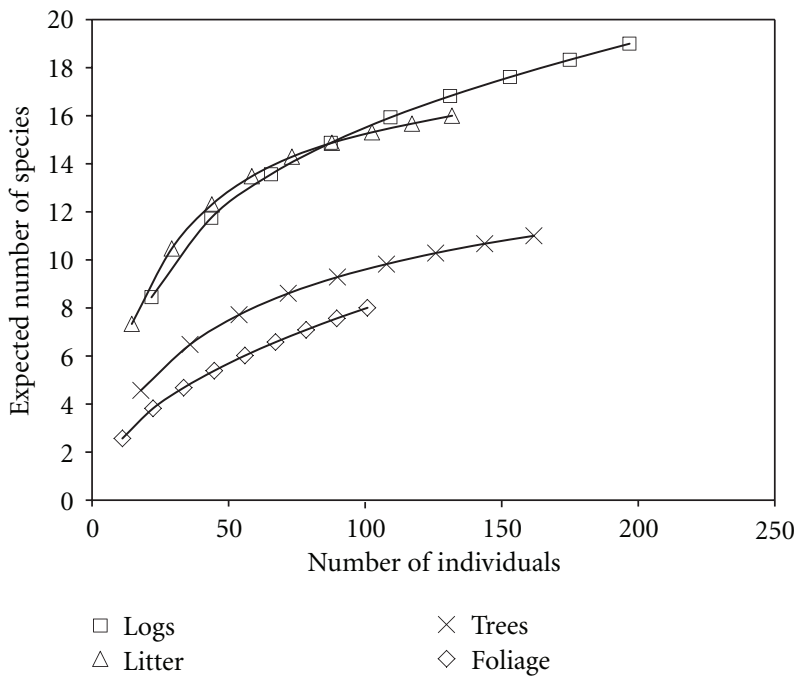

(c)

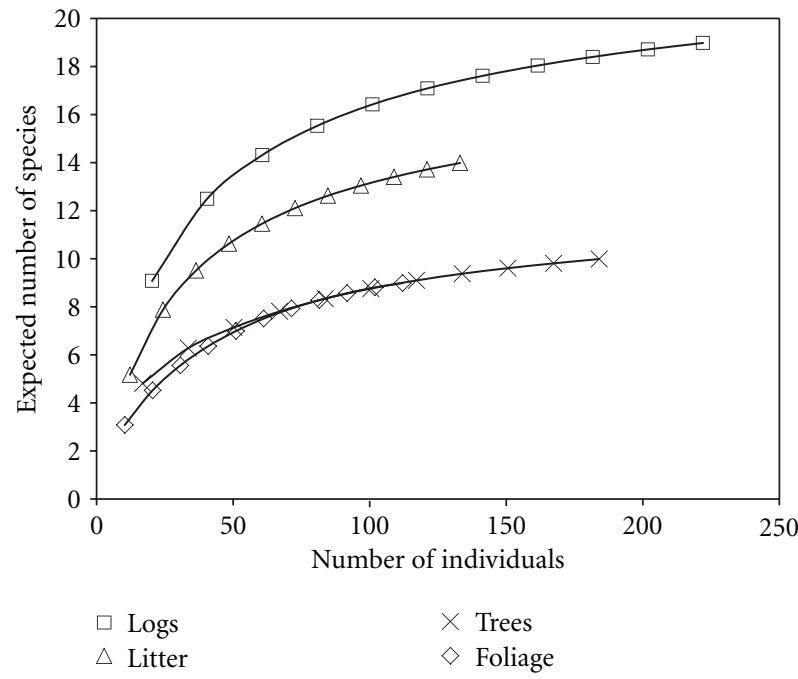

(d)

FIGURE 5: Expected species accumulation curves comparing observed species richness between microhabitats and forest ages. (a) Logs and trees sampled in young secondary, mature secondary, and primary forests during the day. (b-d) Logs, leaf litter, foliage, and trees sampled during the night in (b) young secondary, (c) mature secondary, and (d) primary forests.

[48] collected from a fern approximately $25 \mathrm{~m}$ above the ground. P. signata was previously collected from an epiphytic bromeliad [48], suggesting that this species rarely occupies microhabitats associated with the leaf litter and understory.

Microhabitat used by harvestmen is highly variable and harvestmen may use a variety of microhabitats for different purposes. Use of microhabitats may vary by time of day $[6,49,50]$ or life history stage $[8]$. For example, individuals of some gonyleptid species seek diurnal refuge in caves and only leave at night to forage $[49,50]$. Several species inhabit leaf cutter ant nests [51], while others occupy bromeliads [52] or rely on bromeliads for reproduction [53]. Individuals of some temperate sclerosomatid species are known to make vertical migrations_climbing on trees during the day and descending at dusk to forage on or near the ground $[6,17,18]$. In montane rainforests of Trinidad, two syntopic species belonging to the family Cranaidae often use fallen palm frond sheaths as diurnal shelter [22] or oviposition sites $[45,54,55]$. The use of the endocarp of a coconut as an oviposition site was also observed for a cranaid harvestman [56]. In this study, we observed harvestmen using microhabitats as diurnal refuge as well as nocturnal foraging and mating sites. Over the course of our field studies, we have not observed any oviposition sites, suggesting that most species in this community probably use egg hiding strategies (as opposed to egg guarding) or were not reproductively active during the months that we collected samples (June-August). However, the presence of many cosmetid, stygnommatid and sclerosomatid nymphs (Table 3) suggests that several species are reproductively 


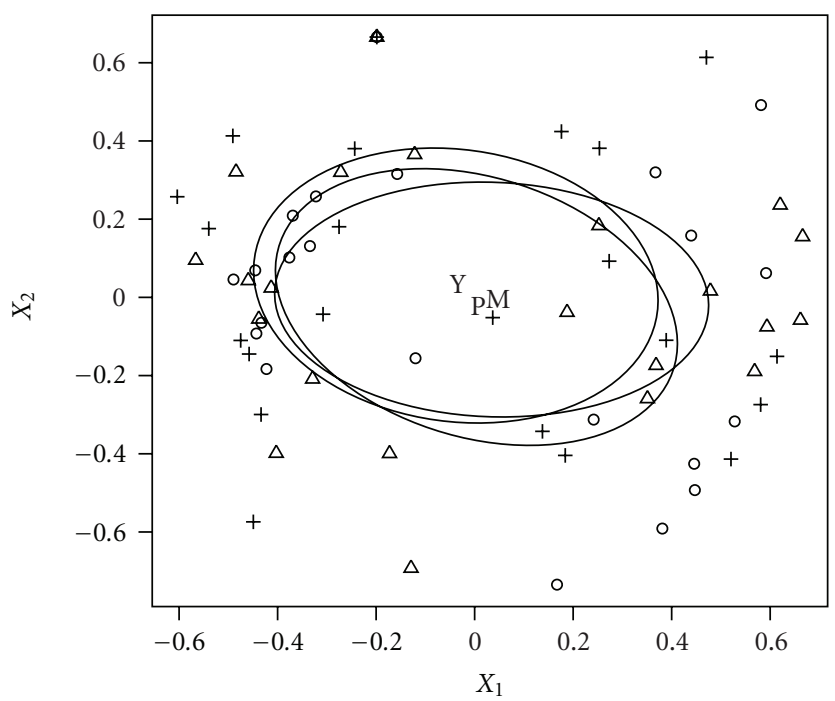

(a)

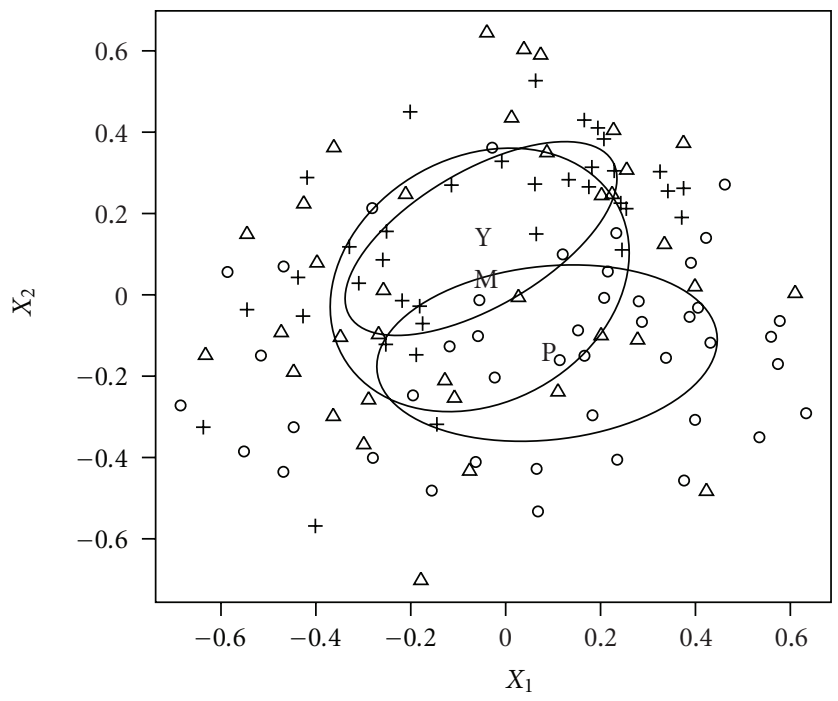

(c)

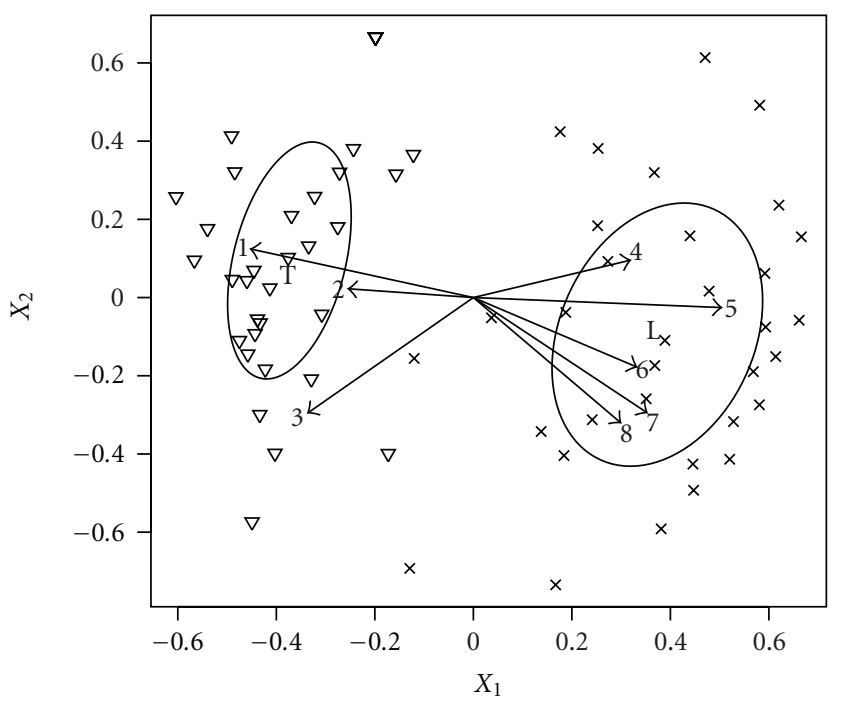

(b)

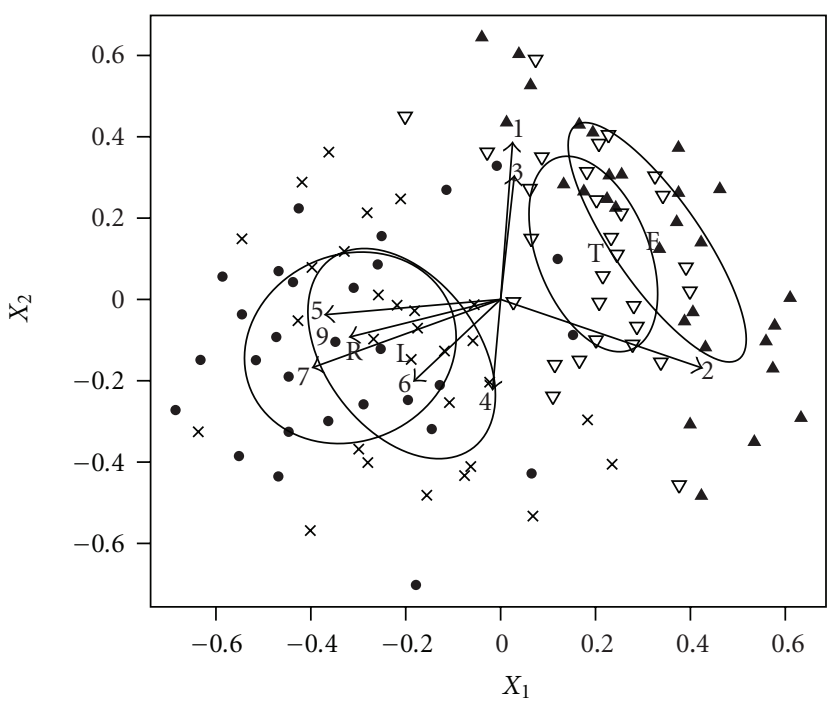

(d)

FIgURE 6: Nonmetric multidimensional scaling ordination using a Bray-Curtis dissimilarity matrix of $\log (x+1)$ transformed data for abundance of harvestmen. (a-b) Samples collected during the day ( $n=66$ sites) comparing species composition between logs and trees across three forest ages. (c-d) Samples collected during the night $(n=29$ sites with four microhabitats sampled at each site) across three forest ages. (a) Variation in species composition was not explained by differences between three successional forests. (b) A high degree of dissimilarity was observed between the two microhabitats during the day. (c) A small amount of variation in species composition was detected between three successional forests for night samples. (d) A high degree of similarity was observed for ground/litter layer microhabitats (i.e., leaf litter and logs) and for microhabitats in the shrub/tree layer that are associated with climbing (i.e., trees and foliage). The ground/litter layer was markedly dissimilar from the shrub/tree layer. Ellipses represent standard deviation. Fitted vectors illustrate correlations between the ordination space of sample sites and indicator species: 1 = Prionostemma sp. $1 ; 2=$ Cynorta marginalis; $3=$ Prionostemma sp. $2 ; 4=$ Paecilaema sp. 1; 5 = Ethobunus albitrochanteris; $6=$ Eucynorta sp. $1 ; 7=$ Glysterus sp. $1 ; 8=$ Prionostemma sp. 3; $9=$ Metopilio ornatipes). $\mathrm{Y}$ : young secondary forest; $\mathrm{M}$ : mature secondary forest; $\mathrm{P}$ : primary forest; $\mathrm{L}: \operatorname{logs} ; \mathrm{R}$ : leaf litter; $\mathrm{T}$ : trees; F : foliage.

active during this time and probably employ egg hiding strategies.

4.3. Leg Length and Climbing Behavior. There is very little empirical evidence available to support the relationship between leg length and climbing behavior. Leg length is suggested to play a major role in the distribution of species between ground/litter layer and shrub/tree layer habitats, but this pattern has only been reported for temperate species [23]. The correlation between leg morphology and habitat use may also be related to tarsal number [4]. In sclerosomatid harvestmen, the large number of tarsal segments aids individuals in grabbing on to small diameter objects by tightly wrapping the leg segments around the object $[57,58]$. 


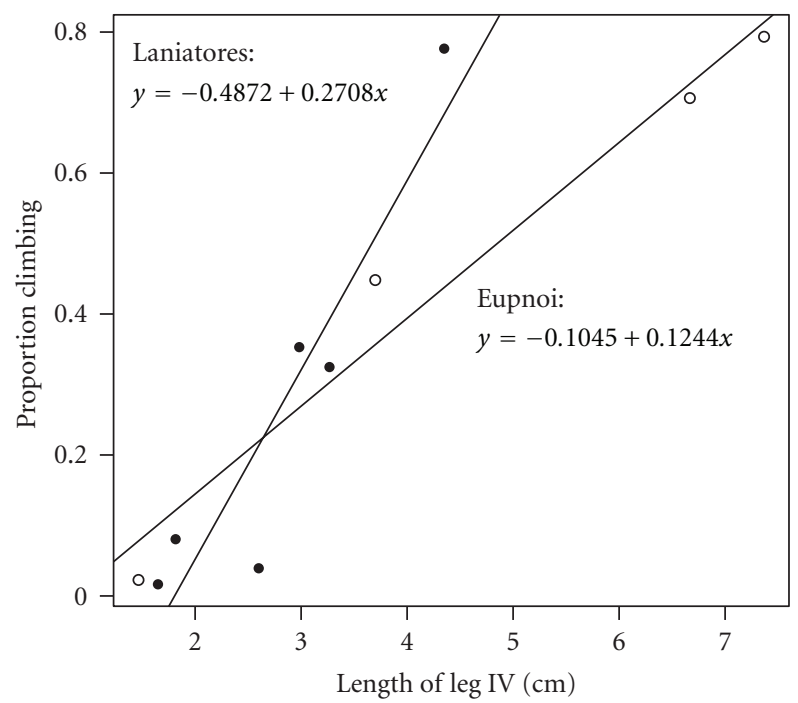

Figure 7: Analysis of covariance for proportion of individuals climbing as a function of length of leg IV while controlling for differences between the suborders Eupnoi and Laniatores. The ANCOVA was significant (Adjusted $R^{2}=0.8895, F_{3,6}=25.15, P<$ 0.001 ) and the significant interaction between leg length and suborder indicates a difference in the slopes between Laniatores and Eupnoi $\left(F_{1,6}=7.876, P=0.031\right)$. However, suborder had no significant effect indicating that there was no difference in the intercept of the relationship for the two taxa $\left(F_{1,6}=0.964, P=\right.$ $0.364)$.

Although no such behavior has been reported for Laniatores, Curtis and Machado [4] report that species of Gonyleptidae that often climb vegetation exhibit an increased number of tarsal segments on legs III and IV compared to closely related species that live mostly on the ground.

Our analysis of covariance supported the hypothesis that longer leg length is positively related to climbing behavior. Our analysis also revealed differences in the relationship between leg length and climbing behavior among the two suborders. The small, ground dwelling, sclerosomatid species $M$. ornatipes exhibited a relatively shorter leg length than other sclerosomatid harvestmen at our study site. However, this species possessed a much greater number of tarsal segments than syntopic species belonging to Laniatores. For example, on leg II, M. ornatipes possessed 47-62 tarsal segments and Prionostemma spp. possessed 77-125 segments. In contrast, the six species of Laniatores had 715 tarsal segments on leg II. Legs I, III, and IV exhibited similar patterns (Table 4). The nonsignificant intercept term for the relationship between leg length and proportion of individuals climbing (Figure 7) indicated that the shortlegged species for both taxa are largely ground-dwelling species. However, the significant difference in the slopes of the regression lines (Figure 7) for Laniatores and Eupnoi indicated that the relationship between leg length and proportion of individuals climbing differed among the two taxa as leg length increased. We hypothesize that the observed differences between the two suborders are largely due to leg morphology, especially number of tarsal segments, which may influence climbing behavior differently for these taxa.

For the Phalangiidae, Adams [23] observed that ground dwelling species had the shortest leg lengths (12.5 and $19.1 \mathrm{~mm}$ ), species collected from trees had the longest leg lengths (46.5 and $57.3 \mathrm{~mm}$ ) and one species with an intermediate leg length $(44.6 \mathrm{~mm})$ was collected from both habitats. In our study, for the Sclerosomatidae (Eupnoi), $M$. ornatipes had the shortest leg IV length and was most often collected from the ground/litter layer, Prionostemma sp. 3 had an intermediate leg IV length and was found equally in both the ground/litter layer and shrub/tree layer, and Prionostemma spp. 1 and 2 had the longest leg IV length and was most often found in the shrub/tree layer (Table 4). The Laniatores demonstrated a similar pattern based on six species for which we were able to collect enough habitat use data (i.e., the most abundant species). Of the six species of Laniatores, C. marginalis possessed the longest leg length and was commonly found climbing in the shrub/tree layer while Glysterus sp. had the shortest leg length and was almost exclusively found in the ground/litter layer habitat (Table 4). For E. albitrochanteris (Zalmoxidae), mean length of leg IV may be slightly biased because males of this species exhibit an elongate leg IV while females have much shorter legs. Several other species of the genera Ethobunus and Pachylicus exhibit similar sexually dimorphic leg IV [59]; however, the elongated legs of these male zalmoxids are considerably shorter than leg IV of climbing species of Laniatores (Table 4).

4.4. Influence of Forest Age. For communities of harvestmen, forest fragmentation negatively impacts both relative abundance and species richness [3], but community structure across successional forests has not previously been examined. We investigated the species assemblage response to local, small-scale differences in habitat structure by comparing the species composition, richness, and abundance across three adjacent successional forests at La Selva. These forest stands, although categorized by age in our study, differed in many respects including previous land use, soil types, vegetation, understory growth, and other biotic and abiotic factors, and our goal was therefore to examine the response of harvestmen assemblages to differences in habitat structure and not the succession of the harvestmen assemblage.

For diurnal samples, we did not detect any differences in species composition, relative abundance, or species richness between forest ages. In contrast, for nocturnal samples, we observed differences in species composition and relative abundance among the three successional forests. Primary forest and young secondary forest showed the greatest differences in species composition, while mature secondary forest was relatively similar to both. Species richness did not differ among forest ages. We attribute these observed differences in species composition and abundance among forest ages for nocturnal samples, but not diurnal samples, to the fact that most species of harvestmen are more active at night [4]. Since our nocturnal samples were standardized by time spent searching an area along a transect, these data 
revealed differences among forest ages based the number of individuals within a large area. Our diurnal samples, however, were standardized by the number of logs or trees sampled $(n=5)$ at each site as opposed to an area along a transect. Therefore, if distribution and density of individuals are influenced by density and availability of microhabitats, then these methods used for diurnal sampling would fail to reveal differences among forest ages. In contrast, the methods employed for nocturnal sampling inherently accounted for differences in density and availability of microhabitats among the forest ages. Therefore, nocturnal sampling provided a better representation of the species composition and relative abundance of the assemblage within each forest age, while diurnal sampling revealed differences only among microhabitats. Whether the availability of microhabitat space influences the spatial distribution and density of harvestmen is an important question that should be addressed.

We observed that the long-legged, climbing sclerosomatids (i.e., Prionostemma sp. 1 and Prionostemma sp. 2) as well as the small, short-legged, ground dwelling zalmoxids and stygnommatids were correlated with young forest and were much more abundant in this forest type (Figure 4). In contrast, many cosmetids were associated with primary forest including ground dwelling species (e.g., E. albipustulata and Paecilaema sp. 1) as well as species that were commonly observed climbing on trees or foliage (e.g., C. marginalis). We hypothesize that these differences reflect variation in habitat availability, including the density of understory shrubs and rotting logs. For example, the young secondary forest features a higher density of understory vegetation than primary forest [60]. This understory should provide climbing species such as Prionostemma spp. with much more preferable microhabitat space. Although the distribution of harvestmen within communities in temperate regions is not directly correlated with shrub density or ground cover [25], different patterns may exist in communities in tropical regions. Interestingly, in primary forest where Prionostemma spp. (Sclerosomatidae) exhibited relatively low abundance, C. marginalis (Cosmetidae) exhibited the highest abundance. Thus, these species may compete for some limited resource that influences their relative abundance. The effects of interand intraspecific competition on composition of harvestmen communities are poorly understood [4], and the coexistence of Prionostemma spp. and C. marginalis may serve as an ideal system to examine these mechanisms.

\section{Acknowledgments}

This research was supported by a University Fellowship and funding from the Graduate Student Organization at the University of Louisiana at Lafayette (DNP). The authors thank Deedra McClearn, Ronald Vargas, Bernal Matarrita, Danilo Brenes, Francisco Campos, and staff members at the Organization for Tropical Studies for supporting their work at La Selva Biological Station. They are grateful to Carlos Víquez and the helpful staff at INBio for continued support of their work in Costa Rica. They appreciate the insightful comments of Justin Nowakowski and Paul Leberg regarding statistical analyses, and Maria Jose Rodriguez-Mora for revisions to the Spanish abstract. Assistance in the field was provided by Megan Gibbons, Lexi Sack, Anna Bianchi, Charles Yeager, Kelly Gronemeyer, and Rachel Curtis. They thank Rebekah Pine, Scott Shasty, and Whitney Brackin whose initial work on this fauna led to their study. They are grateful to Nicole Michel, Wes Testo, and Eddie Watkins who helped to locate several rare species. Specimens collected in the field were exported to the USA under scientific passport numbers 01607 (VRT) and 05130 (DNP).

\section{References}

[1] R. Pinto-Da-Rocha, M. B. Da Silva, and C. Bragagnolo, "Faunistic similarity and historic biogeography of the harvestmen of southern and southeastern Atlantic Rain Forest of Brazil," Journal of Arachnology, vol. 33, no. 2, pp. 290-299, 2005.

[2] S. L. Boyer, R. M. Clouse, L. R. Benavides et al., "Biogeography of the world: a case study from cyphophthalmid Opiliones, a globally distributed group of arachnids," Journal of Biogeography, vol. 34, no. 12, pp. 2070-2085, 2007.

[3] C. Bragagnolo, A. A. Nogueira, R. Pinto-da-Rocha, and R. Pardini, "Harvestmen in an Atlantic forest fragmented landscape: evaluating assemblage response to habitat quality and quantity," Biological Conservation, vol. 139, no. 3-4, pp. 389400, 2007.

[4] D. J. Curtis and G. Machado, "Ecology," in Harvestmen: The Biology of Opiliones, R. Pinto-da-Rocha, G. Machado, and G. Giribet, Eds., pp. 280-308, Harvard University Press, Cambridge, Mass, USA, 2007.

[5] W. S. Bristowe, "The distribution of harvestmen (Phalangida) in Great Britain and Ireland, with notes on their names, enemies and food," Journal of Animal Ecology, vol. 18, no. 1, pp. 100-114, 1949.

[6] V. Todd, "The habitats and ecology of the British harvestmen (Arachnida: Opiliones), with special reference to those of the Oxford district," Journal of Animal Ecology, vol. 18, no. 2, pp. 209-229, 1949.

[7] G. C. Williams, "Seasonal and diurnal activity of harvestmen (Phalangida) and spiders (Araneida) in contrasted habitats," Journal of Animal Ecology, vol. 31, no. 1, pp. 23-42, 1962.

[8] A. L. Edgar, "Studies on the biology and ecology of Michigan Phalangida (Opiliones)," Miscellaneous Publications, vol. 144, pp. 5-63, 1971.

[9] R. Pinto-da-Rocha, "Opiliones," in Biodiversidade do Estado de São Paulo, Brasil: Invertebrados terrestres, C. R. F. Brandão and E. M. Cancello, Eds., pp. 35-44, FAPESP, São Paulo, Brazil, 1999.

[10] N. F. Lo-Man-Hung, T. A. Gardner, M. A. Ribeiro-Júnior, J. Barlow, and A. B. Bonaldo, "The value of primary, secondary, and plantation forests for neotropical epigeic arachnids," Journal of Arachnology, vol. 36, no. 2, pp. 394-401, 2008.

[11] M. Almeida-Neto, G. Machado, R. Pinto-da-Rocha, and A. A. Giaretta, "Harvestman (Arachnida: Opiliones) species distribution along three Neotropical elevational gradients: an alternative rescue effect to explain Rapoport's rule?" Journal of Biogeography, vol. 33, no. 2, pp. 361-375, 2006.

[12] C. Bragagnolo and R. Pinto-da-Rocha, "Diversidade de opiliões do parque nacional da Serra dos Órgãos, Rio de Janeiro, Brasil (Arachnida: Opiliones)," Biota Neotropica, vol. 3, no. 1, pp. 1-20, 2003.

[13] A. B. Kury, "Annotated catalogue of the Laniatores of the New World (Arachnida, Opiliones)," Revista Ibérica de Aracnologia, vol. 1, pp. 1-337, 2003. 
[14] A. B. Kury and R. Pinto-da-Rocha, "Gonyleptidae," in Harvestmen: The Biology of Opiliones, R. Pinto-da-Rocha, G. Machado, and G. Giribet, Eds., pp. 196-203, Harvard University Press, Cambridge, Mass, USA, 2007.

[15] A. B. Kury and R. Pinto-da-Rocha, "Cosmetidae," in Harvestmen: The Biology of Opiliones, R. Pinto-da-Rocha, G. Machado, and G. Giribet, Eds., pp. 182-185, Harvard University Press, Cambridge, Mass, USA, 2007.

[16] V. R. Townsend Jr., C. Víquez, P. A. Vanzandt, and D. N. Proud, "Key to the species of Cosmetidae (arachnida, opiliones) of Central America, with notes on penis morphology and sexual dimorphisms," Zootaxa, vol. 2414, pp. 1-26, 2010.

[17] G. F. Grether and Z. R. Donaldson, "Communal roost site selection in a neotropical harvestman: habitat limitation vs. tradition," Ethology, vol. 113, no. 3, pp. 290-300, 2007.

[18] R. R. Wade, E. M. Loaiza-Phillips, V. R. Townsend Jr., and D. N. Proud, "Activity patterns of two species of neotropical harvestmen (Arachnida: Opiliones) from Costa Rica," Annals of the Entomological Society of America, vol. 104, no. 6, pp. 1360-1366, 2011.

[19] N. Šajna, P. Kušar, L. S. Novak, and T. Novak, "Notes on thermo- and hygropreference in Leiobunum roseum C. L. Koch, 1839 (Opiliones: Sclerosomatidae) in a habitat of Hladnikia pastinacifolia Reichenbach, 1831 (Spermatophyta: Apiaceae)," Contributions to Natural History, vol. 12, no. 3, pp. 1111-1123, 2009.

[20] J. C. Cokendolpher, W. P. MacKay, and M. H. Muma, "Seasonal population phenology and habitat preferences of montane harvestmen (Arachnida: Opiliones) from Southwestern New Mexico," Southwestern Naturalist, vol. 38, no. 3, pp. 236-240, 1993.

[21] C. Komposch and J. Gruber, "Vertical distribution of harvestmen in the Eastern Alps (Arachnida: Opiliones)," Bulletin of the British Arachnological Society, vol. 11, no. 4, pp. 131-135, 1999.

[22] D. N. Proud, J. A. Tibbetts, M. K. Moore, and V. R. Townsend Jr., "Diversity of neotropical harvestmen (Arachnida: Opiliones) inhabiting logs and palm fronds in the rain forests of Trinidad," Annals of the Entomological Society of America, vol. 104, no. 2, pp. 241-248, 2011.

[23] J. Adams, "The habitat and feeding ecology of woodland harvestmen (Opiliones) in England," Oikos, vol. 42, no. 3, pp. 361-370, 1984.

[24] D. R. Jennings, M. W. Houseweart, and J. C. Cokendolpher, "Phalangids (Arachnida: Opiliones) associated with strip clear-cut and dense spruce-fir forests in Maine," Environmental Entomology, vol. 13, no. 5, pp. 1306-1311, 1984.

[25] D. T. Corey and I. Jack Stout, "Ground surface arachnids in sandhill communities of Florida," Journal of Arachnology, vol. 18, no. 2, pp. 167-172, 1990.

[26] H. Vehviläinen, J. Koricheva, and K. Ruohomäki, "Effects of stand tree species composition and diversity on abundance of predatory arthropods," Oikos, vol. 117, no. 6, pp. 935-943, 2008.

[27] P. D. Hillyard and J. H. P. Sankey, "Harvestmen: keys and notes for the identification of the species," in Synopses of the British Fauna (Linnean Society of London), vol. 4, pp. 1-119, E. J. Brill, Great Britain, 1989.

[28] R. E. Ricklefs and D. B. Miles, "Ecological and evolutionary inferences from morphology: an ecological perspective," in Ecological and Evolutionary Inferences from Morphology: An Ecological Perspective, P. C. Wainwright and S. M. Reilly, Eds., pp. 13-41, University of Chicago Press, Chicago, Ill, USA, 1994.
[29] C. S. Elton and R. S. Miller, "The ecological survey of animal communities: with a practical system of classifying habitats by structural characters," Journal of Ecology, vol. 42, no. 2, pp. 460-496, 1954.

[30] L. A. McDade and G. S. Hartshorn, "La Selva biological station," in La Selva: Ecology and Natural History of a Neotropical Rain Forest, L. A. McDade, K. S. Bawa, H. A. Hespenheide, and G. S. Hartshorn, Eds., pp. 6-14, University of Chicago Press, Chicago, Ill, USA, 1994.

[31] R. L. Sanford Jr., P. Paaby, J. C. Luvall, and E. Phillips, "Climate, geomorphology, and aquatic systems," in La Selva: Ecology and Natural History of a Neotropical Rain Forest, L. A. McDade, K. S. Bawa, H. A. Hespenheide, and G. S. Hartshorn, Eds., pp. 19-33, University of Chicago Press, Chicago, Ill, USA, 1994.

[32] Organization for Tropical Studies, "Map of land use in 2000," 2011, http://www.ots.ac.cr.

[33] S. C. Goslee and D. L. Urban, "The ecodist package for dissimilarity-based analysis of ecological data," Journal of Statistical Software, vol. 22, no. 7, pp. 1-19, 2007.

[34] R Development Core Team, "R: a language and environment for statistical computing," R Foundation for Statistical Computing, Vienna, Austria, 2010, http://www.R-project.org.

[35] R. Kindt, F. G. Blanchet, J. Oksanen et al., "vegan: community ecology package,” R package version 1.17-4, 2010, http://CRAN.R-project.org/package=vegan.

[36] R. K. Colwell, "EstimateS: statistical estimation of species richness and shared species from samples," Version 8.0, 2006, http://purl.oclc.org/estimates.

[37] N. J. Gotelli and R. K. Colwell, "Quantifying biodiversity: procedures and pitfalls in the measurement and comparison of species richness," Ecology Letters, vol. 4, no. 4, pp. 379-391, 2001.

[38] W. W. Daniel, Applied Nonparametric Statistics, Houghton Mifflin Company, Boston, Mass, USA, 1978.

[39] C. F. Roewer, "Ergebnisse der Österreichischen biologischen Costa-Rica-Expedition 1930-IV. Teil. Opilioniden," Annalen des Naturhistorischen Museums in Wien, vol. 46, pp. 275-295, 1933.

[40] C. F. Roewer, "Die familie der cosmetiden opilioneslaniatores," Archiv für Naturgeschichte, vol. 78, no. 10, pp. 1$122,1912$.

[41] G. P. Quinn and M. J. Keough, Experimental Design and Data Analysis for Biologists, Cambridge University Press, Cambridge, UK, 2002.

[42] N. Banks, "Arachnida from Costa Rica," Proceedings of the Academy of Natural Sciences of Philadelphia, vol. 61, no. 2, pp. 194-234, 1909.

[43] C. F. Roewer, "Diagnosen neuer gattungen und arten der opiliones-laniatores (Arachn.). Weitere weberknechte XII. Cosmetidae," Senckenbergiana, vol. 28, no. 1, pp. 7-57, 1947.

[44] J. Halaj and A. B. Cady, "Diet composition and significance of earthworms as food of harvestmen (Arachnida: Opiliones)," American Midland Naturalist, vol. 143, no. 2, pp. 487-491, 2000.

[45] D. H. Morse, "Harvestmen as commensals of crab spiders," Journal of Arachnology, vol. 29, no. 2, pp. 273-275, 2001.

[46] P. A. Latreille, "Mémoire pour servir de suite á l'histoire des insectes connus sous le nom de Faucheurs. Phalangium. L," Bulletin des Sciences par la Société Philomathique, vol. 1, no. 15, pp. 113-115, 1798.

[47] J. A. Burns, R. K. Hunter, and V. R. Townsend, "Tree use by harvestmen (Arachnida: Opiliones) in the rainforests of 
Trinidad, W.I," Caribbean Journal of Science, vol. 43, no. 1, pp. 138-142, 2007.

[48] N. Banks, "Notes on some Costa Rican Arachnida," Proceedings of the Academy of Natural Sciences Philadelphia, vol. 65, no. 3, pp. 676-687, 1913.

[49] P. Gnaspini, "Population ecology of Goniosoma spelaeum, a cavernicolous harvestman from south-eastern Brazil (Arachnida: Opiliones: Gonyleptidae)," Journal of Zoology, vol. 239, no. 3, pp. 417-435, 1996.

[50] G. Machado, R. L. G. Raimundo, and P. S. Oliveira, "Daily activity schedule, gregariousness, and defensive behaviour in the Neotropical harvestman Goniosoma longipes (Opiliones: Gonyleptidae)," Journal of Natural History, vol. 34, no. 4, pp. 587-596, 2000.

[51] E. A. Maury and A. Pilati, "Comensalismo de Riosegundo birabeni (Canals, 1943) (Opiliones, Gonyleptidae) en hormigueros de Acromyrmex lobicornis (Emery, 1887) (Hymenoptera, Formicidae)," Revista del Museo Argentino de Ciencias Naturales, vol. 142, pp. 1-7, 1996.

[52] M. A. González-Sponga, Arácnidos de Venezuela: Opiliones Laniatores II. Familia Cosmetidae, Academia de Ciencias Físicas, Matemáticas y Naturales, Caracas, Venezuela, 1992.

[53] G. Machado and P. S. Oliveira, "Maternal care in the neotropical harvestman Bourguyia albiornata (Arachnida: Opiliones): oviposition site selection and egg protection," Behaviour, vol. 139, no. 11-12, pp. 1509-1524, 2002.

[54] R. K. Hunter, D. N. Proud, J. A. Burns, J. A. Tibbetts, and V. R. Townsend Jr., "Parental care in the neotropical harvestman Phareicranaus calcariferus (opiliones, cranaidae)," Journal of Arachnology, vol. 35, no. 1, pp. 199-201, 2007.

[55] V. R. Townsend Jr., D. N. Proud, and M. K. Moore, "Harvestmen (Arachnida: Opiliones) of Trinidad, West Indies," Living World, vol. 2008, pp. 53-65, 2008.

[56] V. R. Townsend Jr., D. N. Proud, A. H. Savitzky, and M. V. Marshall, "Use of coconut endocarp as an oviposition site by a neotropical harvestman (Opiliones: Cranaidae)," Living World, vol. 2011, pp. 70-71, 2011.

[57] A. Kaestner, Invertebrate Zoology, vol. 2, Wiley, New York, NY, USA, 1967.

[58] C. Guffey, V. R. Townsend Jr., and B. E. Felgenhauer, "External morphology and ultrastructure of the prehensile region of the legs of Leiobunum nigripes (Arachnida, Opiliones)," Journal of Arachnology, vol. 28, no. 2, pp. 231-236, 2000.

[59] A. B. Kury and A. Pérez González, "Zalmoxidae," in Harvestmen: The Biology of Opiliones, R. Pinto-da-Rocha, G. Machado, and G. Giribet, Eds., pp. 243-246, Harvard University Press, Cambridge, Mass, USA, 2007.

[60] M. S. Laska, "Structure of understory shrub assemblages in adjacent secondary and old growth tropical wet forests, Costa Rica," Biotropica, vol. 29, no. 1, pp. 29-37, 1997. 

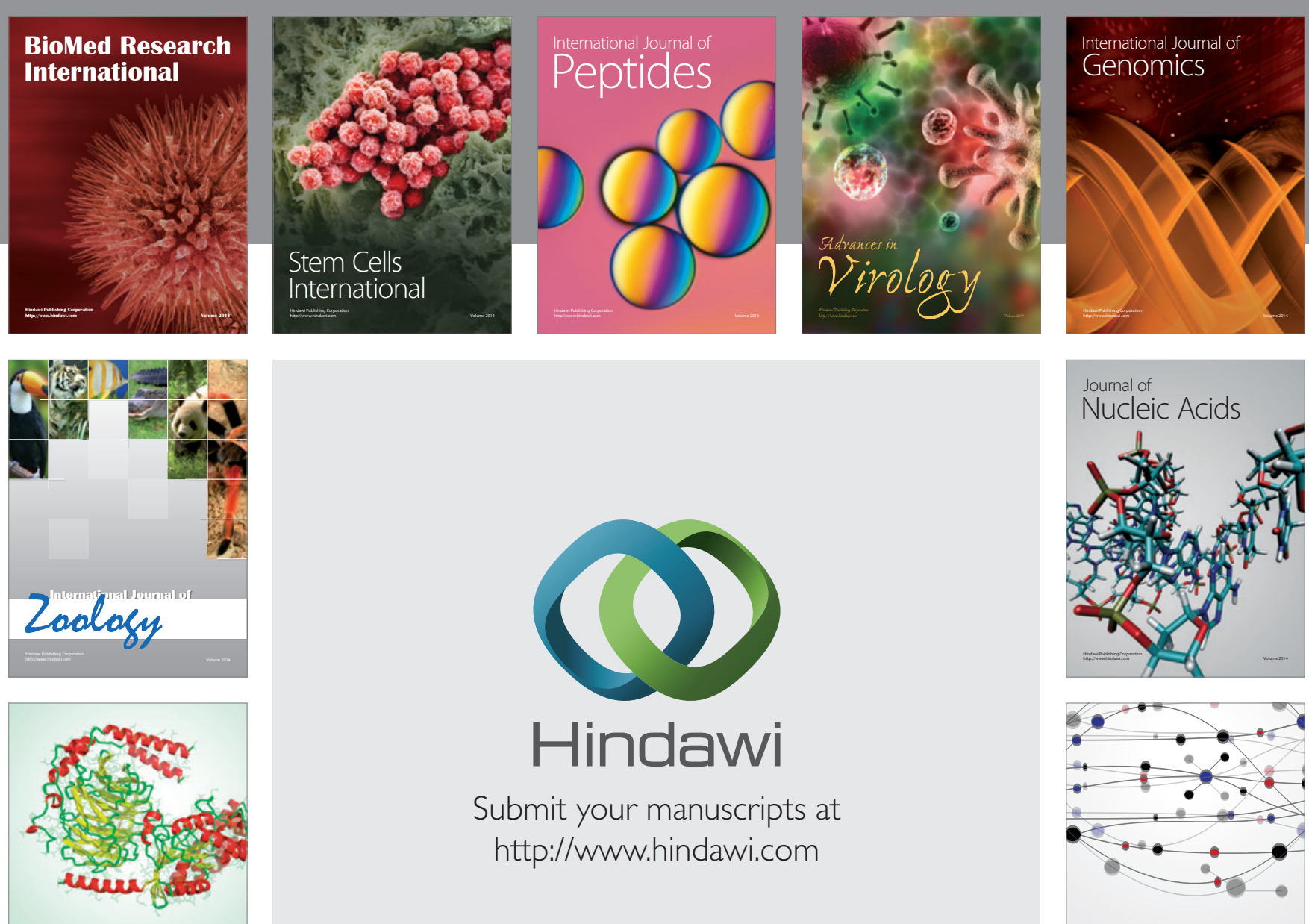

Submit your manuscripts at

http://www.hindawi.com

Signal ${ }^{\text {Jumal }}$ Transduction
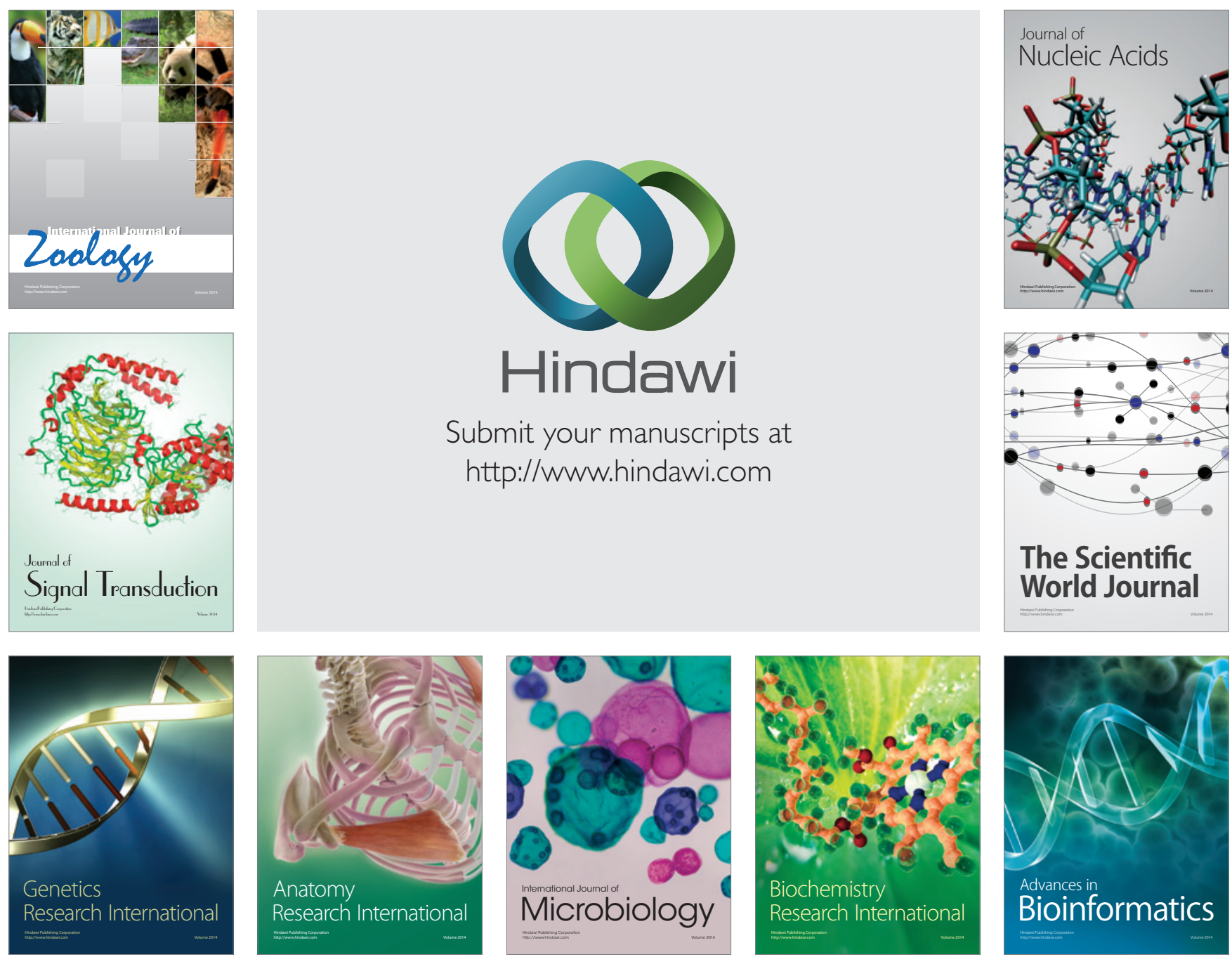

The Scientific World Journal
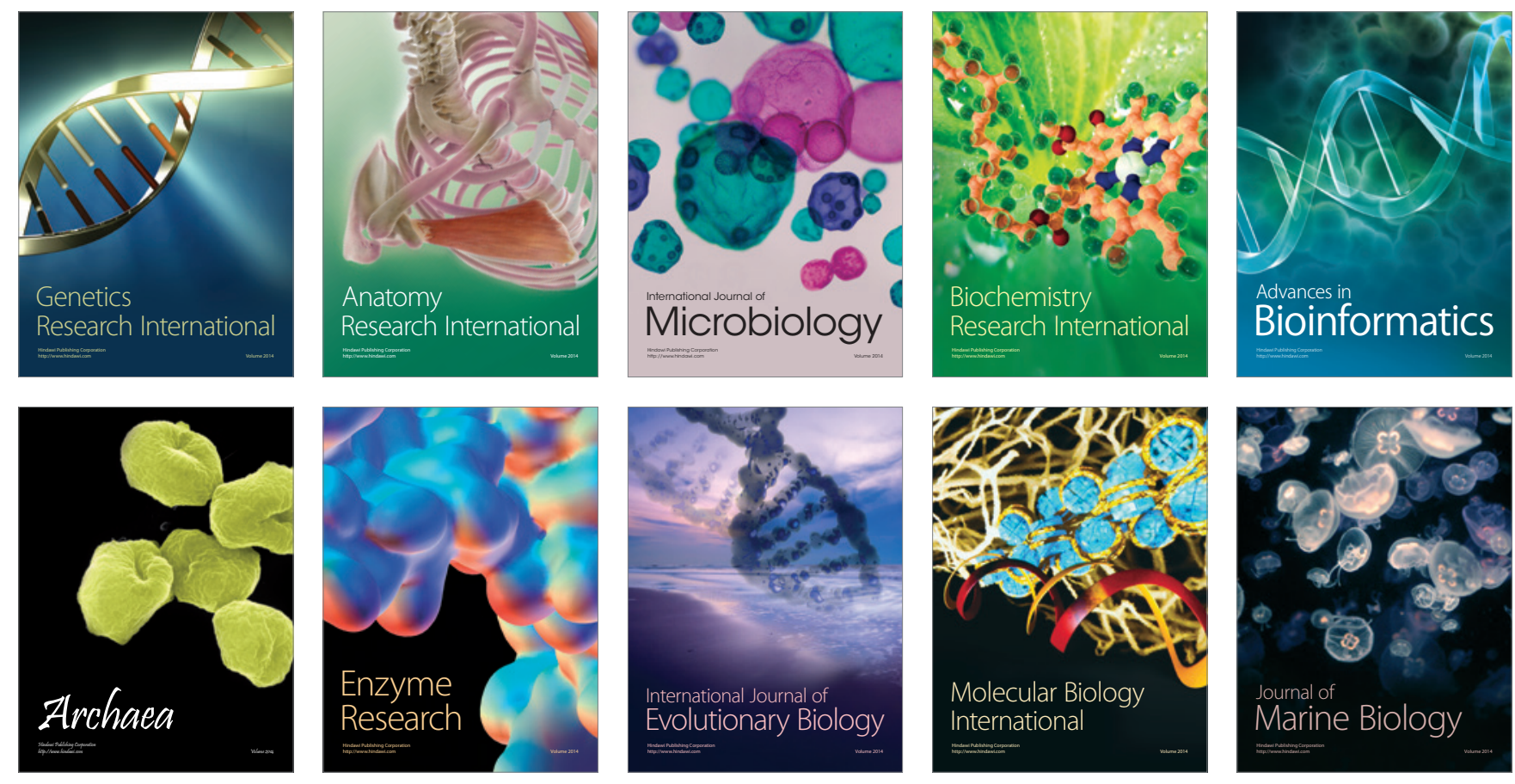